\title{
A review of Gobiid expansion along the Danube-Rhine corridor - geopolitical change as a driver for invasion
}

\author{
K.F. Roche ${ }^{(1), \star}$, M. Janač, P. Jurajda \\ Received May 15, 2013 \\ Revised July 11, 2013 \\ Accepted July 18, 2013
}

Key-words:

Gobiidae,

Danube,

Rhine, range expansion, drivers

\section{ABSTRACT}

Five Gobiid fish species have recently increased their ranges along the Danube/Rhine river corridor. Studies to date, however, have tended to be local, site specific and reactive, examining just one or few species. As such, overall range has tended to be assumed based on a summary of patchy, and sometimes contradictory, data. This study provides an upto-date literature review of first records of occurrence for all five species along their expansion route. In addition, available shipping data are examined to identify possible proximal causes of introduction. Three main discontinuous population centres were identified; all at or near important container ports: Vienna, Duisburg and Rotterdam. Shipping is confirmed as an important factor in the rapid national and international expansion of Ponto-Caspian Gobiids, with downstream drift, rip-rap and heavy boat traffic contributing to rapid spread on the Rhine. Geopolitical factors, however, such as the fall of communism and the Balkan conflict, have been key in influencing where, when, and by which route gobies first appear. Rapid expansion of Gobiids in the Rhine raises the possibility of establishment throughout mainland Europe via two new potential invasion corridors across Germany/Poland and France.

\section{RÉSUMÉ}

Une revue de l'expansion des Gobiidae le long du corridor Danube-Rhin les changements géopolitiques comme moteur pour l'invasion

Mots-clés : Gobiidae, Danube, Rhin, expansion d'aire de répartition, paramètre déterminant
Cinq espèces de poissons Gobiidae ont récemment étendu leurs répartitions dans le corridor Danube/Rhin. Les études menées à ce jour ont cependant tendance à être locales, spécifiques au site, et n'examinent seulement qu'une ou quelques espèces. De ce fait, la répartition globale a tendance à être évaluée sur la base d'un résumé de données fragmentaires et parfois contradictoires. Cette étude est une synthèse de la littérature des premiers signalements de présence pour les cinq espèces le long de leur itinéraire d'expansion. En outre, les données de navigation disponibles sont examinées afin de déterminer les causes proximales possibles d'introduction. Trois principaux centres de population disjoints ont été identifiés, tous dans ou près des ports à conteneurs importants : Vienne, Duisbourg et Rotterdam. La navigation est confirmée comme un facteur important dans l'expansion nationale et internationale rapide des Gobiidae pontocaspiens, avec une dérive vers l'aval; les enrochements et la circulation de gros bateaux contribuant à la propagation rapide sur le Rhin. Des facteurs géopolitiques, cependant, comme la chute du communisme et le conflit des Balkans, ont joué un rôle clé en influençant

(1) Institute of Vertebrate Biology, Academy of Sciences of the Czech Republic, v.v.i., Květná 8, 60365 Brno, Czech Republic

* Corresponding author: kevin.roche@hotmail.co.uk 
où, quand et par quelle voie les gobies apparaissent en premier. L'expansion rapide des Gobiidae dans le Rhin soulève la possibilité d'implantation dans toute l'Europe continentale via deux nouveaux corridors d'invasion potentiels à travers l'Allemagne/Pologne et la France.

\section{INTRODUCTION}

The last 25 years have seen a huge increase in the number of publications on invasive fish species, and on Ponto-Caspian Gobiids in particular. This surge in interest appears to have been sparked by the introduction of two Ponto-Caspian fish species, the round goby (Neogobius melanostomus) and Western tubenose goby (Proterorhinus semilunaris), into the Laurentian Great Lakes via ballast water from transoceanic vessels in 1990 (Jude et al., 1992). The US studies also promoted an increase in research in Europe, where it quickly became apparent that many aquatic Ponto-Caspian species (see bij de Vaate et al., 2002; Copp et al., 2005), including five Gobiid fish species, had increased their ranges along European river systems at around the same time. Three of these, bighead goby (Ponticola kessleri), monkey goby ( $N$. fluviatilis), and racer goby (Babka gymnotrachelus), have received far less attention than round and tubenose gobies. While this may originally have been because the species' were not found in the Great Lakes (and hence were not immediately perceived as an invasive threat), in at least two cases (monkey and racer goby) a slower apparent expansion rate (i.e. not found in 'Western' waters until very recently) may also have contributed as early publications were frequently in non-English language journals.

Most European studies to date have tended to be local or national in character (covering relatively short stretches), site specific (e.g. targeting towns or harbours), reactive (undertaken after the species has been found), or examine presence of just one (or few) species. As such, overall range size has tended to be assumed based on a summary of patchy, and sometimes contradictory, data. The majority of studies to date have also tended to imply a relatively straightforward contiguous east to west range expansion from the Black Sea to the Rhine Delta (e.g. see Bíró, 1972; Copp et al., 2005; Harka, 1993; Harka and Bíró, 2007; Ohayon and Stepien, 2007); the rate of expansion being increased through transport via container shipping ballast. While this may be an unavoidable side-effect of summarising such data, it is possible that important information has been lost in the process.

The primary aim of this study, therefore, is to provide an up-to-date and relatively in-depth literature review of first records of occurrence for all five Gobiid species for those countries bordering the expansion route along the Danube/Rhine corridor, one of three east-west invasion routes identified by Jaždžewski (1980) (Figure 1). Such records should provide an overview of population movement along the route, approximate timing of dispersal and main centres of population establishment/introduction. Note, however, that a lack of detailed historical (and often modern) fish survey data can complicate this process, resulting in an unknown 'time-lag' between actual first occurrence and first scientific record. Further, as surveys have often taken place near urban centres or harbours, it may be difficult to separate secondary colonisation via 'rapid' introduction (e.g. via ballast water) or through slower natural expansion (Ohayon and Stepien, 2007). While the increasing use of genetic analysis will go a long way to answering many of the uncertainties caused by such bias, a careful reading of the available data should still provide insight into the expansion process, and perhaps highlight new areas for future research.

A number of explanations have been put forward for the expansion of Gobiids, including climate change, improving water quality, canal construction (including the Rhine-Main-Danube Canal (RMDC)), habitat change and hydraulic engineering (e.g. rip-rap), increased shipping, and 'natural invasiveness potential' (e.g. Ahnelt et al., 1998; Copp et al., 2005; Harka and 


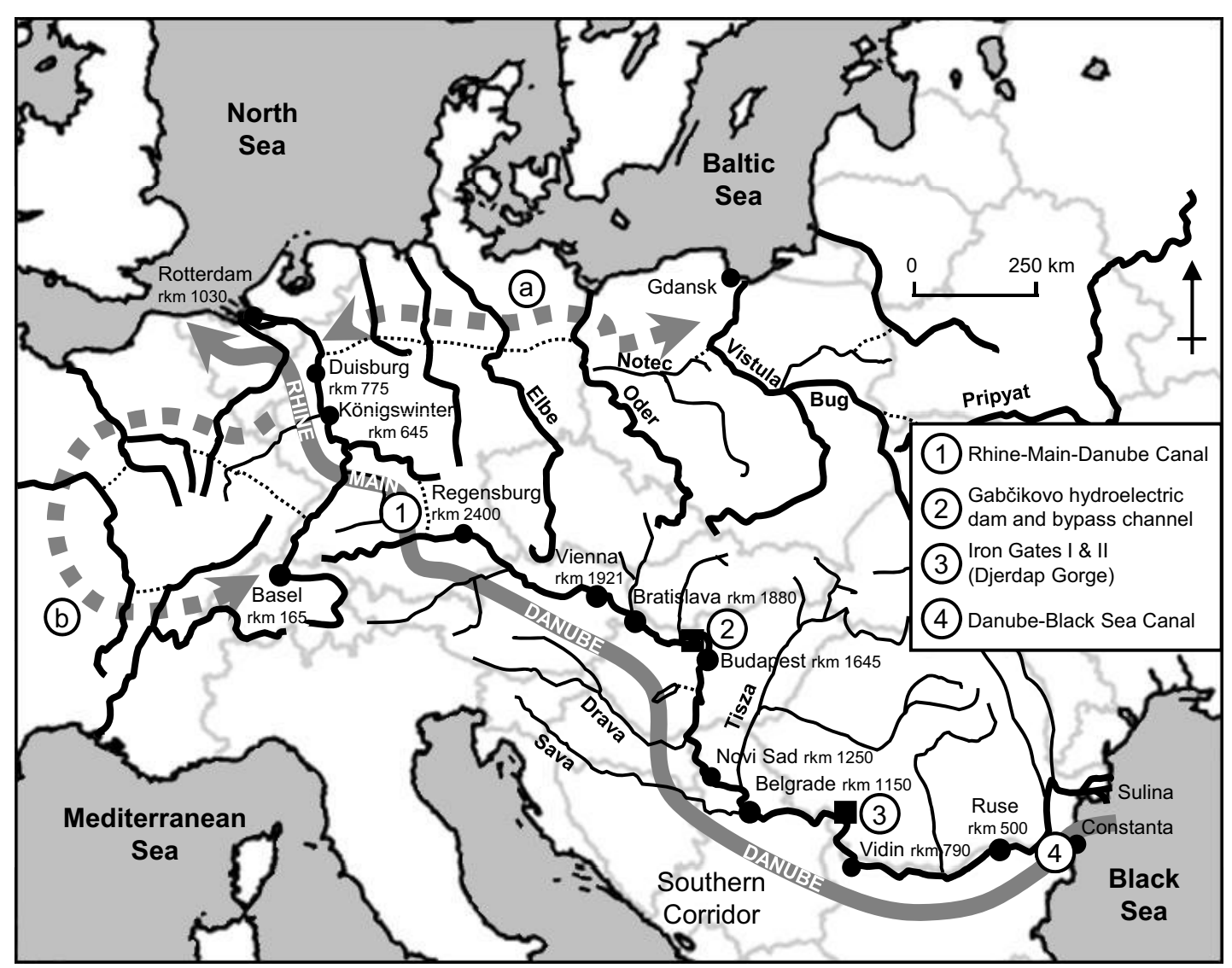

\section{Figure 1}

The main rivers (solid lines) and canals (dotted lines) of Europe with the southern invasion corridor (Danube - Rhine/Main/Danube Canal - Rhine; modified from Jaždžewski, 1980) indicated, along with main cities and ports and physical structures discussed in the main text. (Note that distances are marked in river kilometre [distance from mouth] for the Danube and Rhine kilometre [distance from source] for the Rhine.) The dashed arrows indicate a) a potential German-Polish invasion corridor, and b) a new potential French invasion corridor.

Bíró, 2007; Jude and Scott, 1996; Leuven et al., 2009; van Beek, 2006; Wiesner, 2005). While all of these factors help explain the success of Gobiids once introduced, they do not necessarily explain why they became established when and where they did. For example, interconnection of European river basins through canal construction began in the 17th century (bij de Vaate et al., 2002) and, therefore, cannot account entirely for the sudden peak in range expansion of Gobiids since the 1990s. Likewise, climate change does not explain the successful expansion of round goby into colder Baltic waters in 1990 (Sapota, 2004).

As goby introductions have previously been connected with transfer via shipping ballast water (Ahnelt et al., 1998) and a number of goby first occurrences have undoubtedly taken place in ports (Wiesner, 2005), goby expansion might logically be connected with an increase in total shipping along the invasion route. Indeed, Leuven et al. (2009) noted a significant correlation between increased shipping on the Rhine and non-native macroinvertebrate introductions, while bij de Vaate (2002) observed a strong correlation between shipping and macroinvertebrate introductions along the southern invasion route as a whole. As part of the literature search, therefore, available data on container shipping along the Danube and Rhine were also compared with first records of goby occurrence, and the results discussed in the light of proximal causes of introduction. 


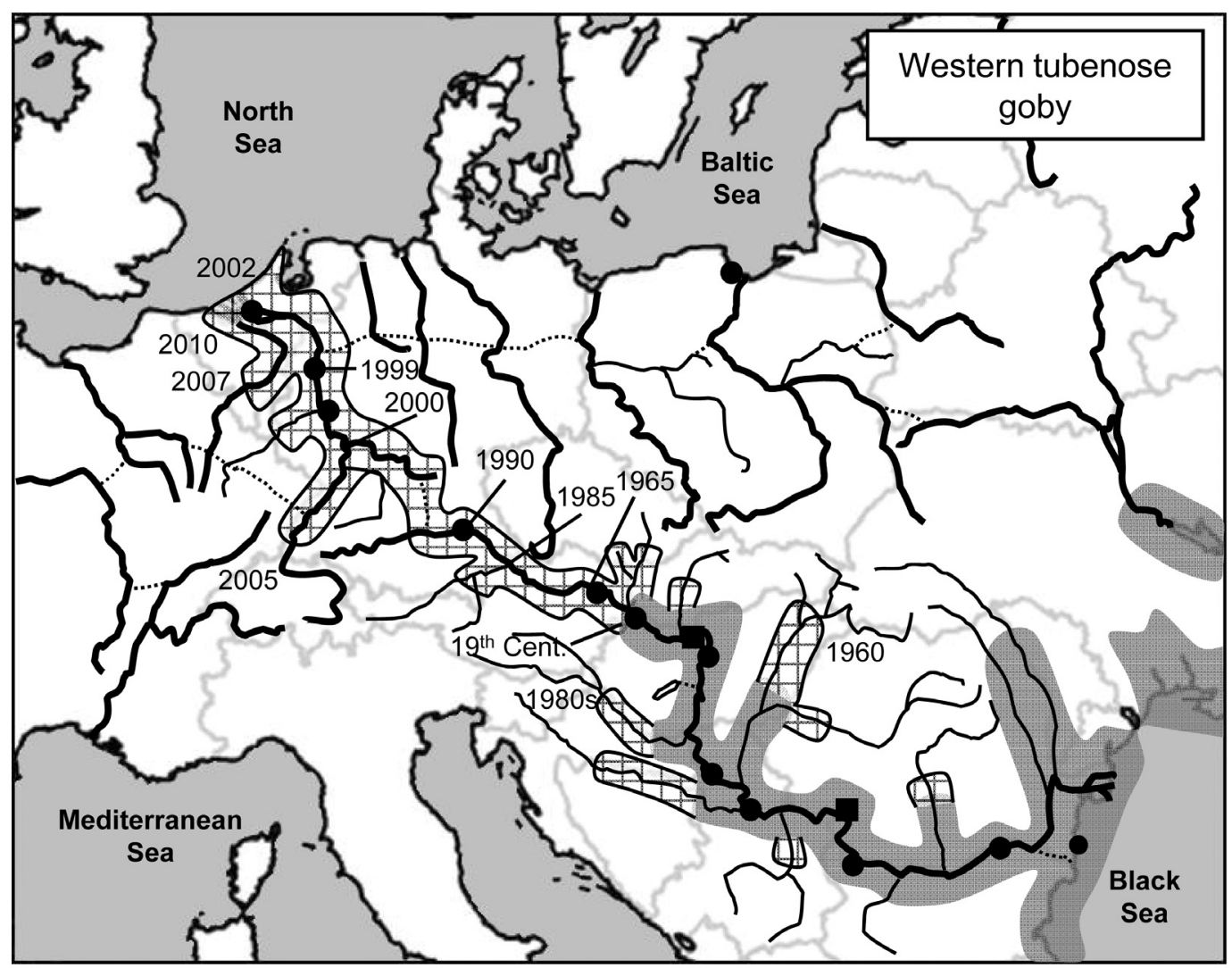

Figure 2

Past (shaded; redrawn after Miller, 2003) and recent (hatched) distribution of the western tubenose goby (Proterorhinus semilunaris). Dates represent first published reports of goby presence.

\section{RESULTS AND DISCUSSION}

\section{> WESTERN TUBENOSE GOBY PROTERORHINUS SEMILUNARIS (HECKEL, 1937)}

Historically, the tubenose goby has had the farthest range up the Danube of all Ponto-Caspian Gobies, being found as far upstream as Vienna and the mouth of the River Morava on the Czech/Slovak border (Figure 2). It had probably migrated to that point soon after the last iceage (ca. 10,000 yrs. BP; Ahnelt, 1989), when the Djerdap Gorge (if it existed) was unlikely to have represented the significant barrier it later became.

According to Harka and Bíró (2007), the first documented report of the tubenose goby is from a creek flowing into the Danube near Budapest (Hungary) in 1872 (Kriesch, 1873; cited in Pintér, 1989). Soon after, it was also observed near the Slovakian capital, Bratislava (Koelbel, 1874) and, not long after, in Lakes Balaton (Vutskits, 1895) and Fertö (Austro-Hungarian border; Mika and Breuer, 1928), where they had presumably been introduced either by anglers or along with stocked fish (but see monkey goby below). In 1957, it was registered $170 \mathrm{~km}$ from the Danube in one of its main tributaries, the River Tisza (southern Hungary; Berinkey, 1972), and confirmed $10 \mathrm{~km}$ up the river in 1960 by Sterbetz (1963). Between 1947 and 1968, it was regularly reported from side-arms and the inundation area of the Slovakian stretch of the Danube, as well as the mouths and estuaries of such northern tributaries as the Rivers Morava, Nitra, Hron, Ipel and adjacent canals (Hensel, 1995; Holčik, 2002). These later findings did not significantly modify the known range of the species from the 19th century (Harka and Bíró, 2007).

Movement outside of this range was first noted in 1965, when tubenose gobies were recorded 200 km upstream in the Austrian stretch of the Danube, from Vienna to Linz (Balon, 1967; 
Bănărescu, 1970), later confirmed by Ahnelt (1988). Numerous other studies have since monitored the species' expansion upstream beyond Slovakia and Austria (e.g. Ahnelt et al., 1998; Harka and Jakab, 2001; Holčik et al., 2003; Jurajda et al., 2005). The species reached Germany (Passau) in 1985, and was recorded $100 \mathrm{~km}$ upstream at Regensburg just a few years later (Reinartz et al., 2000).

Since the 1980s, the species has also spread further up numerous tributaries of the Danube, including the rivers Tisza (Hungary; Harka, 1988), Koros (Romania) and Drava (Croatia; Harka, 1990, 1992; Mrakovčič et al., 1994). In 1994, the species was discovered in the Mušov reservoir on the River Dyje (a tributary of the River Morava, a main tributary of the Danube) in the Czech Republic, apparently introduced by anglers (Hensel, 1995; Lusk and Halačka, 1995). Whereas migration up the Morava from the Danube was initially slow, escapees from the reservoir proceeded to spread rapidly down the Dyje (in part via larval drift) and spread up the Morava from 2000 on (Janáč et al., 2012, 2013; Lusk et al., 2000; Prašek and Jurajda, 2001). In theory, completion of the RMDC in 1992 opened a potential "highway" for species exchange between the Black Sea/Danube and the Rhine/North Sea. First reports of tubenose gobies on the Rhine, however, were from the lower German Rhine (Borcherding et al., 2011b; Reinartz et al., 2000; Figure 2) in 1999; followed by the middle Rhine in 2000 (von Landwüst, 2006); and the Dutch Rhine system in 2002 (Tien et al., 2003; van Kessel et al., 2009). By 2009 , the species was reported as widespread throughout floodplain waters of the lower Rhine, though never at high abundance and primarily in lentic backwaters (Scharbert, 2009). The fact that the species appeared in the downstream stretch of the Rhine before being found further upstream near the RMDC strongly suggests that the species was introduced, probably via ship to Duisburg (Duisburg is the largest inland sea-port in the world, handling seagoing river vessels not only from Europe but also from around the world). In 2005, the species was reported from the German stretch of the River Moselle (von Landwüst, 2006) and along the French bank of the channelised Rhine in 2007 (Manné and Poulet, 2008). Finally, it was reported from Flanders (Belgium) in 2010, in a canal connected to the Border Meuse, having dispersed there from the Netherlands (Cammaerts et al., 2012).

Interestingly, Molnár and Baskar, (1998) reported that, by 1998, tubenose gobies were only rarely caught upstream of Budapest, despite being one of the most common species in the river in previous years. Further, the species was not caught at all in the Slovakian Danube in 2004, being restricted to side-arms off the main river (Jurajda et al., 2005).

\section{> BIGHEAD GOBY PONTICOLA KESSLERI (GÜNTHER, 1861)}

According to Miller (2003), the Djerdap Gorge represented the uppermost range boundary of bighead goby for many years. In 1910, however, the first specimens were caught above the gorge at Banatska Palanka (Vutskits, 1911), presumably having passed through the Sip Channel (an early attempt to allow shipping to navigate the previously impassable Iron Gorge, now covered by the Iron Gorge reservoir (see below)). Few records exist of bighead goby in the area since that time (but see Bănărescu, 1964, "...penetrates up the Danube to Moldova Noua..."), either because few surveys were undertaken or because individuals were rarely able to pass the gorge/channel and form reproducing populations. From the 1970s onward, however, records occur above the Iron Gate Dams and the species appears to show rapid dispersal up the Danube (Figure 3).

In 1986, bighead goby were reported to inhabit the whole Yugoslavian stretch of the Danube (Janković et al., 1987) and the species was known to be common in the Iron Gates reservoir in 1996 (Janković, 1996). However, while a number of authors reported bighead goby to have extended over the whole Hungarian stretch of the Danube (e.g. Pintér (2002) - "reached area between Serbia and Budapest by early 1990s"), and others reported long-distance migrations up tributaries (e.g. Blanc et al. (1971) and Terofal (1984) - "whole Hungarian stretch of River Tisza"), Ahnelt et al. (1998) believed the uppermost distribution of bighead goby by 1998 to be the mouths of the rivers Velka Morava and Nera in Serbia, while Ristić (1977) and Simonović and Nikolic (1996) reported the species only in the mouths of the rivers Velka Morava, Sava 


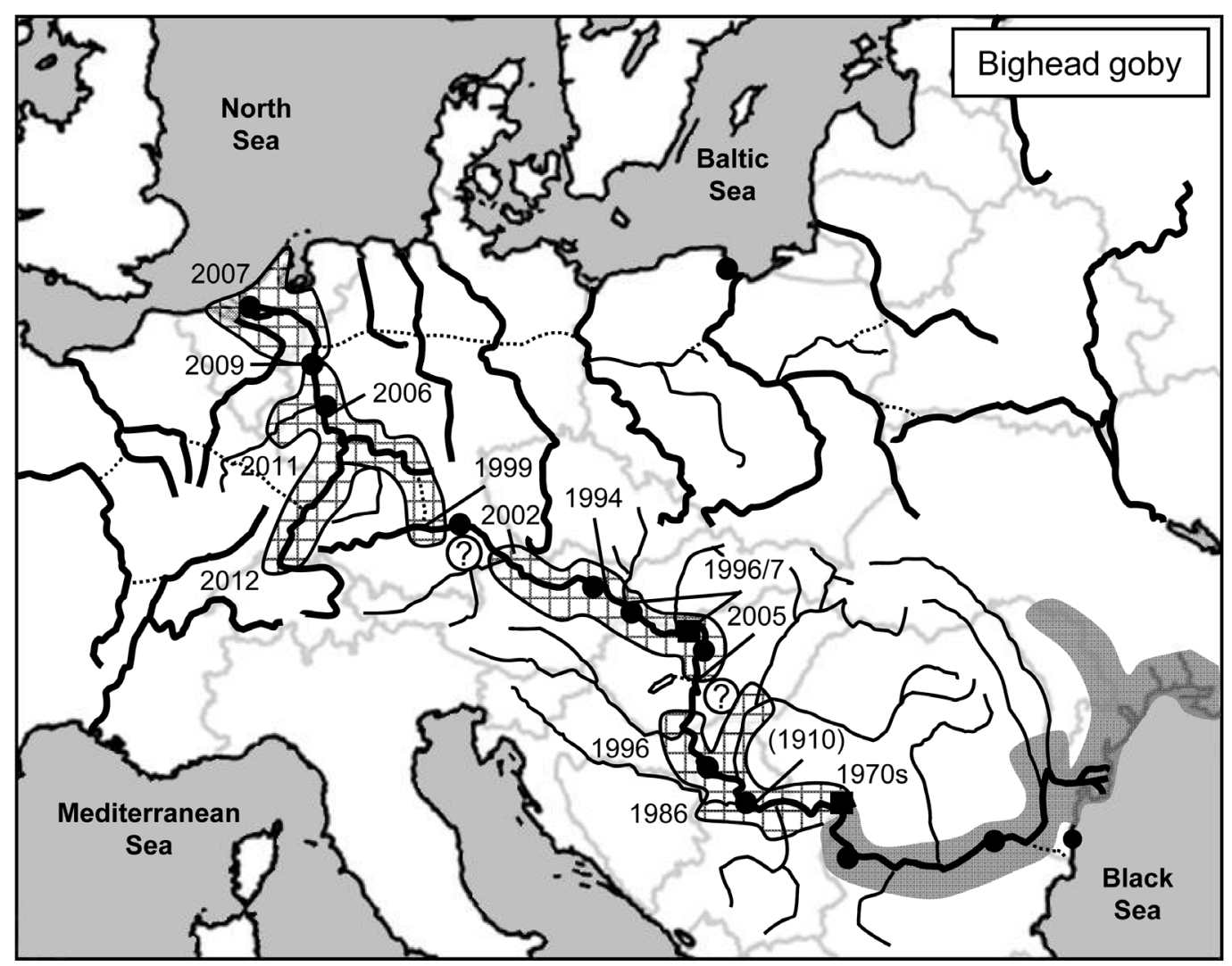

Figure 3

Past (shaded; redrawn after Miller, 2003) and recent (hatched) distribution of the bighead goby (Neogobius kessleri). Dates represent first published reports of goby presence. Question marks indicate possible presence at the time of writing.

and Tisza in Serbia (former Yugoslavia) and in the Danube around Belgrade. In the 1990s, only the tubenose goby had been confirmed in Croatian waters (Mrakovčič et al., 1994). Indeed, no verifying samples of bighead goby were caught in the Hungarian stretch until 1996/97, and those from upstream of Budapest (Erös and Guti, 1997; Molnár and Baskar, 1998), at around the same time as its discovery in Slovak waters (Kautman, 2000; Strán̆ai, 1997). In 2005, the species was registered as common throughout both the Croatian and Slovak stretches of the Danube (Polačik et al., 2008), and low numbers were caught near Baja (rkm 1490), in the south of Hungary (Erös et al., 2005). It is highly unlikely, however, that the species had been able to overcome the distance between Croatia and Slovakia in this time without being recorded in central Hungarian waters. Indeed, the very low numbers caught near Baja suggest the early precursors of a slow naturally advancing population (Polačik et al., 2008).

First records of the species in Austrian waters occur in 1994, when specimens were recorded at rkm 1899 in a backwater near Regelsbrunn, close to the Slovak border (Spindler and Chovanec, 1995; Zweimüller et al., 1996). Two years later (1996/97), they were found downstream for the first time in the Slovak (Kravany - rkm 1741) and Hungarian (Visegrád rkm 1696) stretches (Erös and Guti, 1997; Stránai, 1997). By 2002, the species was common throughout the Austrian section (Wiesner, 2005), despite there having been no reports published for presence below Visegrád (rkm 1696). This strongly suggests rapid downstream migration into Hungarian waters following introduction into Austria, rather than natural upstream migration from Serbia.

The first record of bighead goby in the German stretch of the Danube was at rkm 2334 near Straubing (below the port of Regensburg) in 1999 (Seifert and Hartmann, 2000). At this time, the introduced Austrian population did not extend upstream of the Vienna hydropower dam 
(rkm 1921). In 2000, a few specimens were reported in the bypass channel of the Vienna dam (Prantl, 2001; Weninger, 2001), and a few specimens were registered upstream of the dam (Guttmann, 2001; Schober, 2001). While Wiesner (2005) reported colonisation of the whole Austrian Danube by 2005, density was still low ("due to recent colonisation or poor habitat") and intensive sampling at Engelhartzell (rkm 2199-2200) by Zauner et al. (2001) found no evidence of any Neogobius sp. There is strong evidence, therefore, for a second introduction event in German waters around 1999, probably at the port of Regensburg.

In 2006, bighead gobies were caught near Königswinter (Rhine km 644) on the German Rhine (cit. Borcherding et al., 2011b) and, not long afterwards (2007), the species was reported as widespread in the Dutch Rhine Delta (van Kessel et al., 2009). It remains unclear, however, as to whether the Dutch gobies migrated naturally from the Danube into the German Rhine or were the result of a further introduction by ship. Certainly by 2009 , the German and Dutch 'populations' were connected and the species is now widespread and abundant throughout the Rhine (Borcherding et al., 2011b). The most recent reports are those from the High Rhine in Switzerland, with specimens found at Basel/Kleinhüingen harbour in 2012 (Kalchhauser et al., 2012), and angler's reports from the River Moselle in France in 2011, near the border with Luxembourg (Manné et al. 2013, in press).

While still unconfirmed, it is quite likely that the aforementioned gaps in distribution (see Figure 3) along the Danube were colonised between 2005 and 2012; meaning that, as with tubenose goby, bighead gobies are probably now to be found throughout the Rhine-Danube corridor.

\section{> ROUND GOBY NEOGOBIUS MELANOSTOMUS (PALLAS, 1814)}

Round goby expansion up the Danube appears to have started later than other PontoCaspian species (Harka and Bíró, 2007). In the 1950s, the species was recorded as far upstream as Vidin in Bulgaria (rkm 790; Drensky, 1951), and this was still the case by the late 1980s when Smirnov (1986) reported its presence at Vidin, downstream of the Iron Gates II dam (Figure 4). By 1997, it had progressed only as far as Prahovo in Serbia (rkm 861) and, while it was possibly present in the reservoir, there were no further records of the goby immediately above the Iron Gate Dams (Simonović and Nikolic, 1996; Simonović et al., 1998) until 2005 (Polačik et al., 2008).

The next reported occurrence of round goby was from an industrial harbour at rkm 1917 in 2000, downstream of the Vienna hydropower dam on the Austrian stretch of the Danube (Wiesner et al., 2000). It was also later found by the same authors in the harbour at Krems (rkm 1998). As the same survey found no round gobies outside of the harbour, this appears to be the first positive evidence of an introduction by ship, with the Viennese port of Lobau as the initial introduction site (Wiesner, 2005). There had been no reports from the Hungarian stretch up to that time and occurrence of round goby in the Croatian Danube was still rare by 2005 (Polačik et al., 2008). Though they were later reported as having spread up the River Sava in Croatia in high numbers (Neilson and Stepien, 2009; Piria et al., 2011), it should be noted that the mouth of the Sava is in Serbia (at Belgrade) and there were no reports of round goby in the $137 \mathrm{~km}$ Croatian stretch of the Danube at that time near the border with Serbia. While the round goby was not confirmed in Slovak waters until 2003 (Stránai and Andreji, 2004), Holčik (2003) believed they were probably present much earlier but had been overlooked until then. This is quite probable given the close proximity of the Austrian introduction site upstream. Certainly by 2004 , they were common throughout the Slovak stretch and had been found in the Danube just downstream of the Gabčikovo dam complex (Jurajda et al., 2005; Strán̆ai and Andreji, 2004). While initially present in low numbers (April 2004), they were common by October the same year (Jurajda et al., 2005), indicating a rapid increase in population size. First records in the Hungarian stretch were from 2001 above Budapest (Guti et al., 2003), with reports from just below Budapest in 2003 (cit. Harka and Bíró, 2007). As round gobies had still to be reported upstream of Croatia at this time (Erös et al., 2005; Piria et al., 2011; Polačik et al., 2008), these probably represent downstream migrants from Austria/Slovakia. 


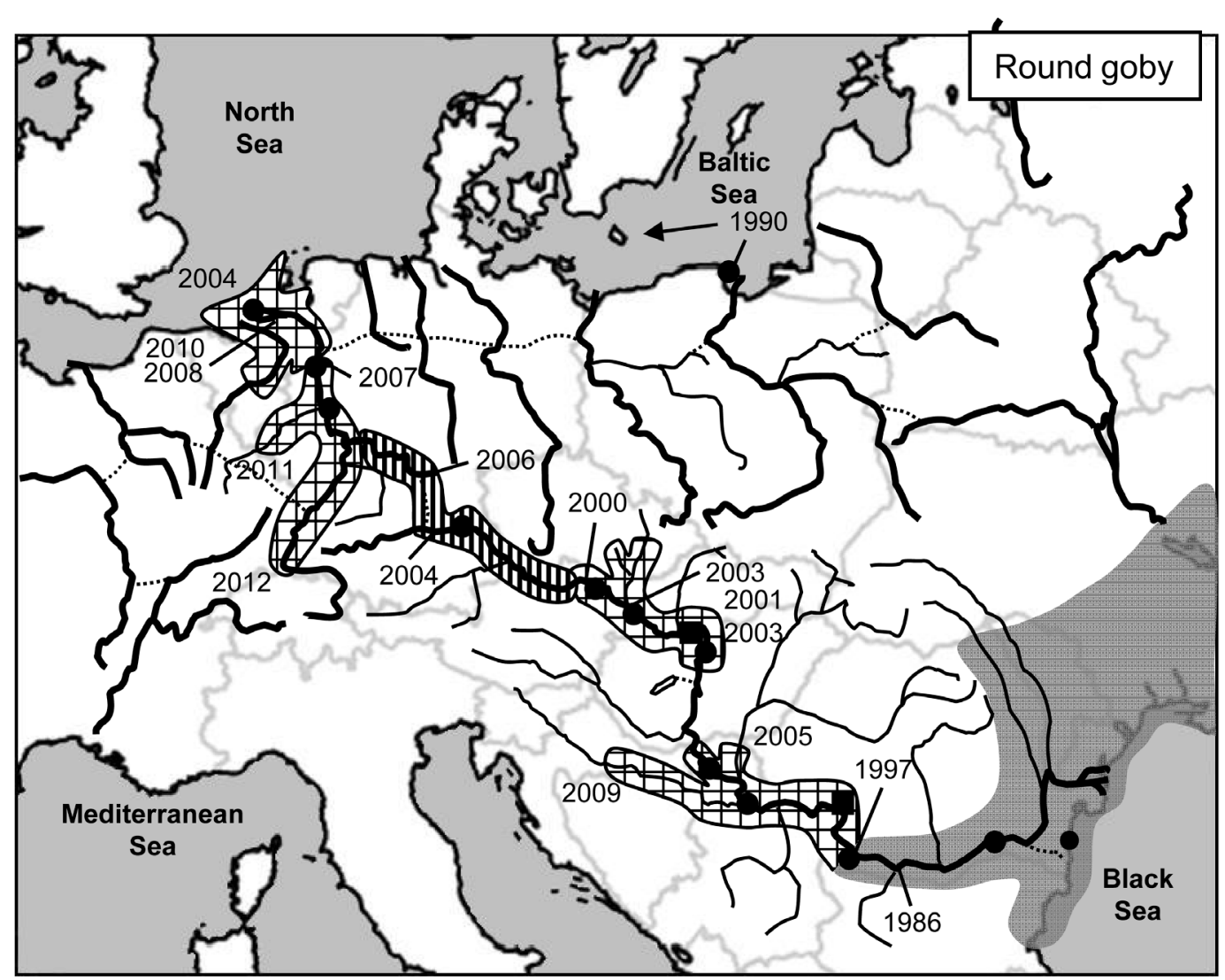

Figure 4

Past (shaded; redrawn after Miller, 2003) and recent (square hatched) distribution of the round goby (Neogobius melanostomus). Dates represent first published reports of goby presence. Vertical hatching indicates range inferred from personal communication reports between 2004 and 2006 (see citations in text).

The next reported westward occurrences of round goby were in 2004 in the Dutch Rhine Delta (van Beek, 2006) and, at almost the same time, in the upper Danube at Straubing, just over the German border with Austria (Paintner and Seifert, 2006). While there are no other published reports of presence in the upper Danube and Rhine at this time, Copp et al., (2005) cite a personal communication in 2004 for presence at Passau, between Vienna and Straubing, while further personal communications from fisheries groups reported by Kalchhauser et al. (2012) also indicate that round gobies may have been present at the RMDC itself in 2006 and on the River Main in 2006/2007. While such unconfirmed reports should be treated with caution, the evidence suggests that relatively rapid colonisation of the upper Danube, and passage over the RMDC into the Main, took place between 2000 and 2007. Reliance on personal communications, however, also highlights the relative lack of published 'scientific' data and regular monitoring for goby presence over large stretches of the Danube/Rhine corridor. The first confirmed sighting of adult round goby on the German Rhine was near the city of Zons (Rhine-km 718) in 2008 (cit. Borcherding et al., 2011b). As first occurrence on the Rhine occurred downstream in the Dutch stretch, and no specimens had been reported from immediately downstream, Borcherding et al. (2011b) offered two possible introduction routes: 1) via marine shipping from the Baltic region, where the species was already common (Sapota, 2004), or 2) via shipping from the Danube through the RMDC; both with subsequent spreading through the German Rhine.

Round goby were reported from Belgium in 2010, where they spread from the Dutch Rhine Delta into the brackish tidal River Scheldt and the Albert Canal near Hasselt, either through introduction via the international harbour at Antwerp or through natural spreading through the 


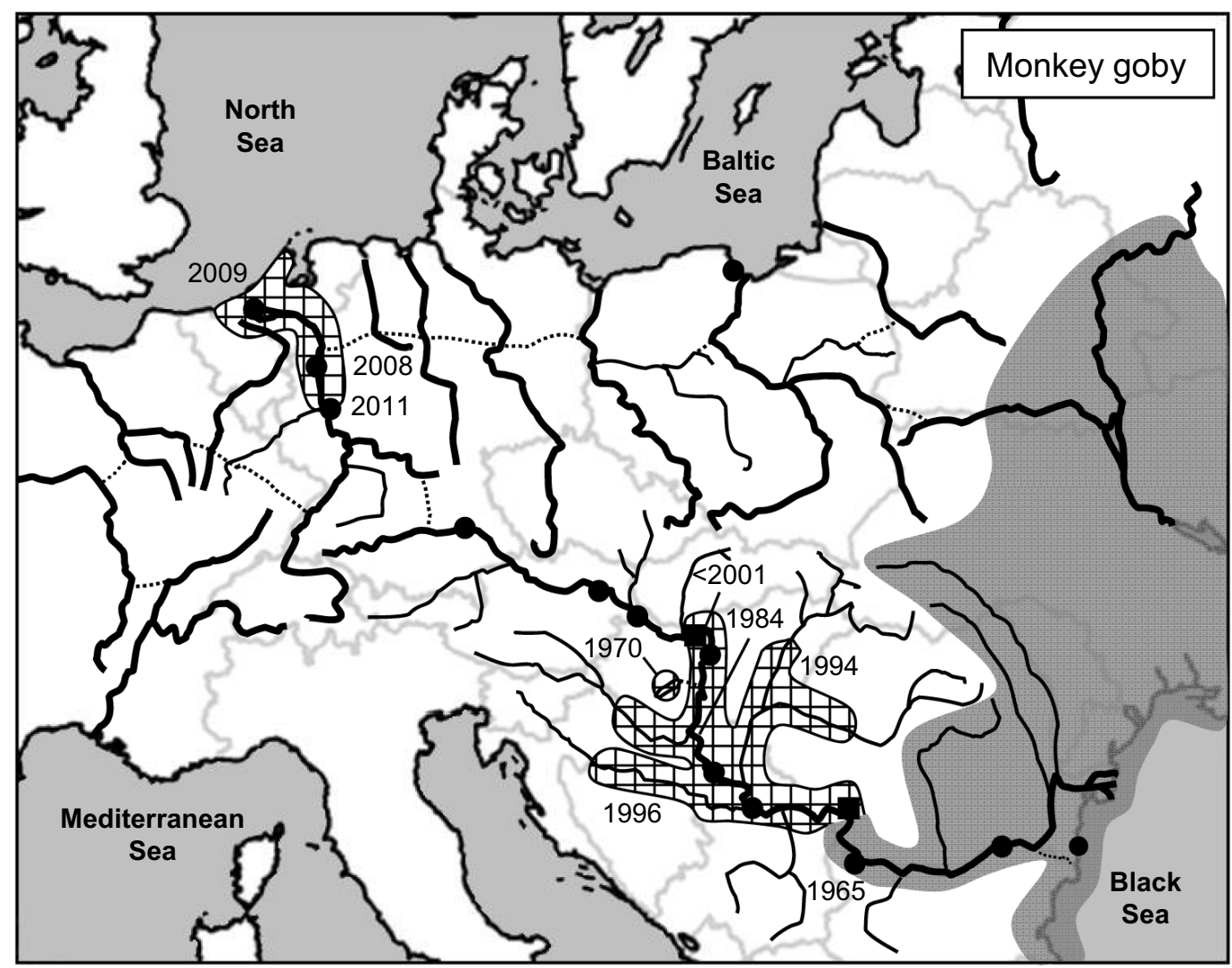

Figure 5

Past (shaded; redrawn after Miller, 2003) and recent (hatched) distribution of the monkey goby (Neogobius fluviatilis). Dates represent first published reports of goby presence.

Rhine-Scheldt Canal (Verreycken et al., 2011). The most recent reports come from the High Rhine in Switzerland, with an established population confirmed at Basel/Kleinhüingen harbour in 2012 (Kalchhauser et al., 2012), and from the River Moselle in France from 2011 on (Manné et al. 2013, in press).

\section{> MONKEY (RIVER) GOBY NEOGOBIUS FLUVIATILIS (PALLAS, 1814)}

There appears to be some confusion over the historic furthest range of monkey goby up the Danube. Estimates for the 1960s include the towns of Ruse (Georgiev, 1966; Svetovidov, 1964), Vidin (Smirnov 1986), downstream of Orsova (rkm 954; Bănărescu, 1964), and below the estuary of the River Porečka (Ristić 1977); all in the Romanian/Bulgarian section below the Djerdap Gorge. The Djerdap Gorge, therefore, appears to have represented a physical boundary to further movement of the species until 1965, when it was first registered $18 \mathrm{~km}$ upstream of the gorge (Bănărescu, 1970), prior to completion of the Iron Gate Dams and reservoir (Figure 5). As construction of the first dam began in 1964, however, there is a likely connection here with its movement upstream. While occurrence was initially rare, the species had become common in the Iron Gates reservoir by the 1990s and went on to colonise the lower reaches of tributaries and fast-flowing brooks (Janković, 1996) as well as several other sites along the Serbian stretch and up into the River Sava (Simonović et al., 1996, 2001). By 2004/05, the species was common in the Croatian Danube (Jurajda et al., 2005). Further migration into the Croatian stretch of the Sava was later noted by Caleta (2007) and Piria et al. (2011).

The first occurrence of monkey goby in Hungarian waters was at some distance from the Danube, in Lake Balaton in 1970 (Harka and Bíró, 2007). First occurrence in the Hungarian 
Danube proper, however, was in 1984 (Pintér, 1989), whereupon it appears to have ceased upstream movement for some time. Around 1993, the species was discovered in the Tisza reservoir system (Harka and Bíró, 2007) and, while the origin of monkey goby in Lake Balaton remains uncertain (Bíró, 1972), its occurrence in the upper course of the Tisza is believed to have occurred through natural migration (Harka, 1993). Its presence was later confirmed in the lower and middle stretches of the Tisza in Serbia and Hungary (Guelmino, 1994; Györe et al., 2001). The species was also later confirmed in rivulets flowing into Lake Balaton (Sió Channel) and in the River Bodrog, an upper tributary of the Tisza (Ahnelt et al., 1998).

By 2001, the species had reached the Hungarian/Slovak border (Holčik et al., 2003; Sallai, 2003; Strán̆ai and Andreji, 2001) and proceeded to spread up the lower part of the River Hron (Strán̆ai and Andreji, 2001). Holcik et al. (2003) believed it to have been present in the stretch earlier than 2001, however, having been overlooked in previous surveys due to its rarity. While monkey goby were reported in the lower River Rába (below Gabčikovo and close to the border with Austria) in 2003 (cit. Harka and Bíró, 2007), Jurajda et al. (2005), following a period of intensive sampling, reported no upstream occurrence of the species on the Danube proper above the town of Komárno (mouth of the River Váh near the Slovak/Hungarian border).

In 2008, monkey goby were confirmed on the German Rhine at the inland sea-port of Duisburg (Stemmer, 2008) and in the Dutch Rhine in 2009 (van Kessel et al., 2009), probably having migrated/drifted downstream from Duisburg. The species was certainly common at Bonn (Rhine-km 665), and slightly less so at Rees (Rhine-km 843), roughly mid-way between these sites in 2010 (Borcherding et al., 2011a, Jurajda personal communication). As there has been no published record of monkey goby from the middle and upper Danube up to the present time, the occurrence at Duisburg certainly represents a further introduction via shipping.

\section{> RACER GOBY BABKA GYMNOTRACHELUS (KESSLER, 1857)}

According to Bănărescu (1964), the racer goby originally extended up the Danube as far as the mouth of the River Mostiștea (rkm 400) in Romania (Figure 6). A number of authors have attempted to summarise the upstream migration of this species (e.g. Harka and Bíró, 2007); however, along with monkey goby, the racer goby is the least studied of the Ponto-Caspian gobies and, as such, the sequence of reports tends to be sketchy and/or contradictory.

The first reports of apparent upstream movement again occur from the 1990s, with reports from the Yugoslavian (now Serbian) stretch of the Danube at Brza Palanka (rkm 884), just below the Iron Gate Dams, in 1991 (Hegediš et al., 1991). Originally described as a new species for Yugoslavia (Hegediš et al., 1991), it was later listed (under Mesogobius gymnotrachelus) as one of the species found in the Djerdap Gorge prior to construction of the Iron Gates I Dam in 1972 (Janković, 1996). This suggests that, as with some of the other Gobiids, the Djerdap Gorge had represented the previous upstream limit and that the species had been overlooked in previous surveys, possibly due to low population density. In 1997, for example, just one specimen was caught at Prahovo (rkm 861), $2 \mathrm{~km}$ below the Iron Gate Dams (Simonović et al., 1998).

No further reports of racer goby occurrence are found until 1999, when 'high numbers' were caught $1000 \mathrm{~km}$ upstream in the Austrian stretch near Regelsbrunn (rkm 1895; Zweimüller et al., 2000; revised by Ahnelt et al., 2001), at almost the same site as bighead goby were first discovered in 1994 (see above). Almost simultaneously, racer goby were caught $50 \mathrm{~km}$ downstream in the Slovak stretch upstream of Bratislava (Ahnelt et al., 2001; Kautman, 2000, 2001). Again, Holčik (2003) suggests that the species was present in Slovak waters earlier than this but overlooked due to its rarity. This is unlikely, however, as it is more probable that the Slovak individuals are part of the same introduction into Austrian waters $50 \mathrm{~km}$ upstream (see Wiesner, 2005), probably via ship to the Viennese port of Hafen Lobau. This is all the more likely as, despite intensive sampling efforts, no specimens were caught along the Hungarian (Erös, 2005; Erös et al., 2005) or Slovak (Jurajda et al., 2005) stretches of the Danube in 2004. Note that the two examples caught in Hungarian waters by Guti et al. (2003) were caught in the Cikola branch system, part of the Hungarian/Slovak floodplain near Gabčikovo 


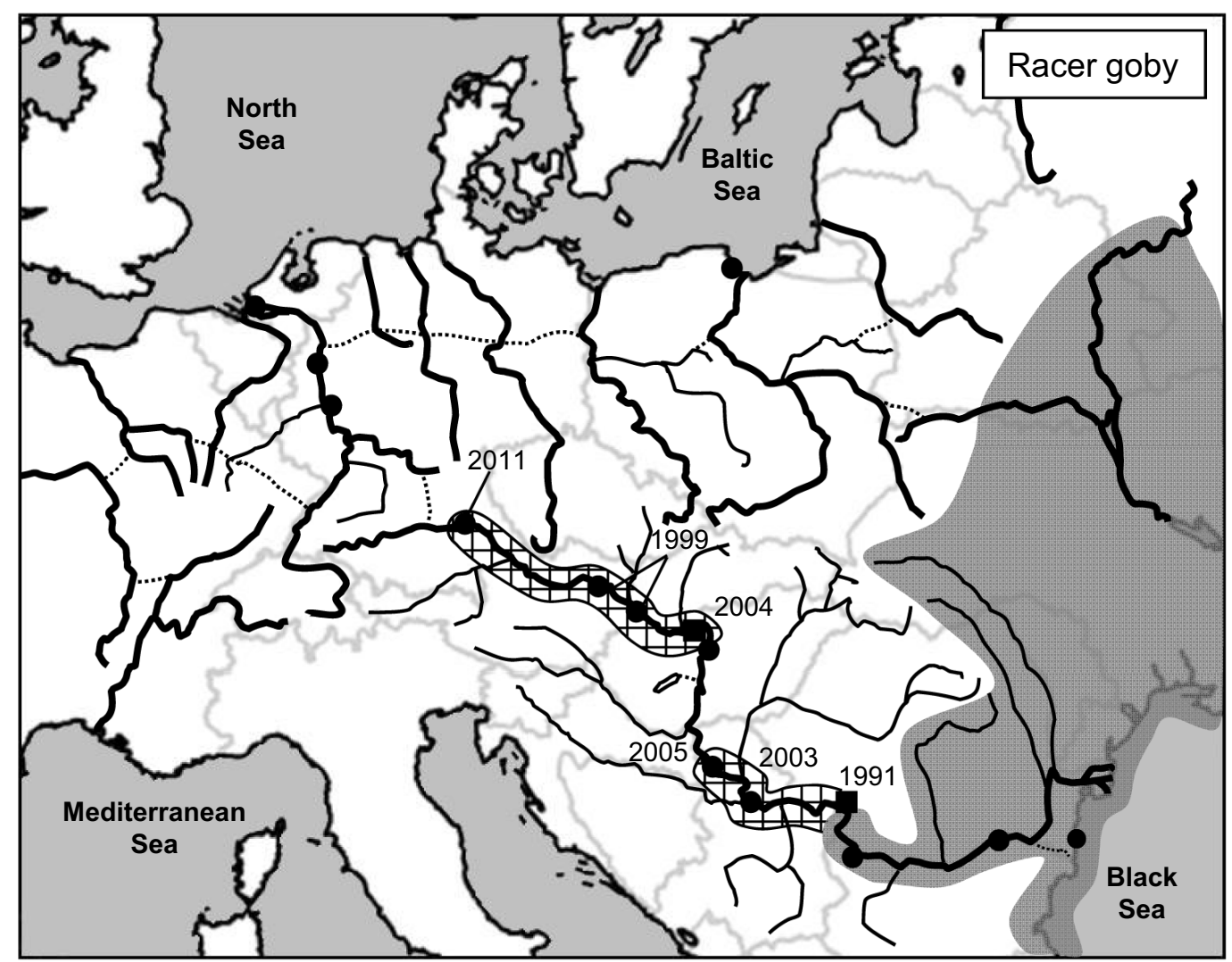

Figure 6

Past (shaded; redrawn after Miller, 2003) and recent (hatched) distribution of the racer goby (Neogobius gymnotrachelus). Dates represent first published reports of goby presence.

and, as such, almost certainly represent downstream migrants from the Austrian/Slovak introduction. Further, Wiesner (2005) reported that racer goby were still confined to the industrial harbour at Vienna in 2004, and were not found between the harbour and the Vienna dam upstream. In 2011, however, the species was recorded in a shallow backwater of the Danube at Regensburg (Haertl et al., 2012). These authors highlight the fact that the species is typically found in shallow, muddy backwaters and imply that the species may have been missed in previous surveys that concentrated on the main channel of the Danube.

In 2003, racer gobies were caught $130 \mathrm{~km}$ upstream of the Iron Gate Dams in the Serbian stretch of the Danube (Visnjic-jeftic and Hegedis, 2004), and were considered locally abundant in both Serbia and Bulgaria in 2005 by Polačik et al. (2008). While the species was also caught by the same authors in Croatia in 2005 , it was very rare and was considered as representing the vanguard of a population spreading upstream. At the time of writing, racer goby has not been reported from between Novi Sad (Croatia) and Budapest (Hungary).

Note also that the reported first occurrence of racer goby in the Rhine reported by Borcherding et al. (2011a) was later confirmed as a misidentified (or hybrid) monkey goby (Haertl et al. 2012) and, therefore, racer gobies have yet to be recorded on the Rhine (Figure 6).

\section{$>$ SHIPPING}

Data for total container shipping on the rivers Danube and Rhine were available from 1950 to 2005 (Figure 7a). Such data are not equally available for all countries along the route due to differing national data collection requirements (e.g. some countries do not collect transit data), changing political commitments and/or conflicts. The general patterns observed, however, are likely to be close to reality and provide a good indication of changes over time. Two 

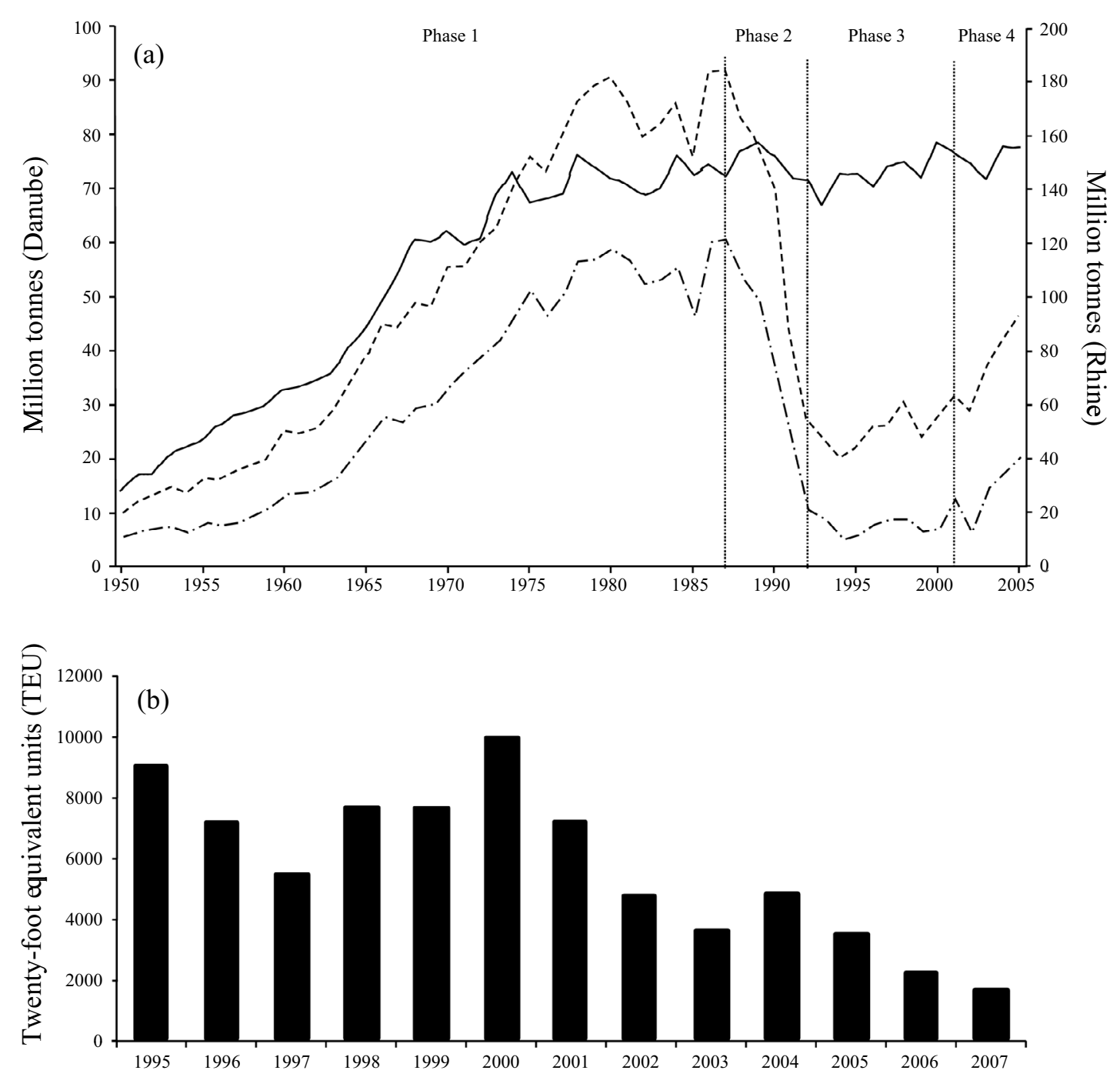

\section{Figure 7}

a) Development of container transport on the rivers Danube and Rhine between 1950 and 2005. The dashed line indicates total container transport entering the Danube from the Black Sea via the Sulina Channel, the dash-dot line indicates total inland container transport along the Danube (left scale; Figure adapted from Mihić and Andrejevic, 2012), and the solid line indicates total international container shipping on the Rhine (right scale; data based on figures for Germany (inc. GDR from 1991); downloaded from DESTATIS (Statistisches Bundesamt, 2012)). b) Container transport on the Rhine-Main-Danube Canal (Figure adapted from UNECE, 2010).

sets of data are shown for the Danube in Figure 7a, total container shipping passing through the Sulina Channel (Danube delta) and total inland container transport (the Sulina channel was used as the Black Sea-Danube Canal did not open until 1984). Both sets of data, however, show almost identical patterns, indicating that almost all shipping entering at Sulina proceeded upriver.

Four basic 'phases' are apparent in the data for the Danube: 1) a period of sustained growth from the 1950s to the late 1970s (related to post-war recovery and increasing globalisation), levelling off through the 80s; 2) a very rapid decline starting around 1987; 3) a period of slow growth at Sulina, but of virtually no growth inland, between 1992 and 2001; followed by 4) a steady increase in shipping from 2001-2 onward. The differences in growth noted during phase 3 suggest that, while shipping entered the Danube at Sulina, very little progressed 
upriver during that period. Shipping figures for the 1990s were at a similar level to the 1960s, and shipping had still not reached levels observed in the 1970s by the mid-2000s.

Container shipping on the Rhine (principally Germany) shows just two main phases; a rapid increase from the 1950s to the 1970s, and continuing but much slower growth from the 1970s to recent times (Figure 7a). Note that the 'levelling' began much earlier than on the Danube, i.e. from the late-60s, and that the early rate of increase was much steeper than for the Danube. By the 1970s, total shipping was around twice that for the Danube, and around 8-times higher by the 1990s. The data for the Rhine and Danube clearly reflect the huge increase in global trade that has taken place since the 1950s, and particularly following the development of container shipping (and roll-on/roll-off lorry transporters) in the 1960s, which has dramatically accelerated the unloading of cargo at ports with appropriate facilities, i.e. specialised cranes, storage space, direct rail/road links (World Ocean Review 1, 2013). The levelling off of growth reflects both the changing economic situation worldwide since the mid-1980s (recession) and also perhaps an increasing difficulty in handling the high numbers of large container ships without substantial reconstruction/deepening of ports and waterways.

Data for the RMDC (opened in 1992) were available from 1995 to 2007 (UNECE 2010; Figure 7b). Total container shipping between the Rhine and the Danube decreased from 1995 to 97 , but increased to its highest level in 2000 . From then on, however, traffic has shown a steady decline.

\section{DRIVERS OF RANGE EXPANSION}

All five Gobiid species have shown evidence of natural migration up the Danube, albeit with differing intensity. Note that, in this sense, 'natural' implies upstream movement between $A$ and $B$ via swimming, and not through 'hitch-hiking', e.g. via shipping. From here on in, therefore, the term 'continuous' is used as regards 'natural' movement, and 'discontinuous migration' or 'jumps' when related exclusively to longer-range movement by shipping.

The tubenose goby would seem to have expanded its range throughout the Danube predominantly by continuous upstream movement alone (Figure 1). It appears to have reached the region around Vienna soon after the last ice-age (Ahnelt, 1989); having passed what is now the Djerdap Gorge before it became a significant barrier. This suggests two things, a) other Gobiid species started continuous migration much later than the tubenose goby, and b) conditions after the formation of the Djerdap Gorge prevented further migration of Gobiid species out of the Black Sea region. Until the 19th century, rocks and associated rapids made the gorge an infamous passage for shipping. In 1890, a spur of the Greben Mountains was removed and rocks cleared over a $2 \mathrm{~km}$ stretch to create the Sip Channel, an $80 \mathrm{~m}$ wide, $3 \mathrm{~m}$ deep channel that was opened for shipping in 1896. Currents remained so strong, however, that ships had to be pulled through by locomotive (Spangler, 2005). Only after the Iron Gate Dams began construction in 1964 (Dam 1 opened 1972), resulting in a $35 \mathrm{~m}$ rise in water level above the dam(s), do we see movement of other goby species beyond this point, apparently starting with bighead goby in the early 1970s (Figure 3). Since then, continuous upstream movement has been slow, with only monkey goby having travelled as far as Budapest, apparently through continuous movement alone (Figure 5).

In addition to continuous expansion, however, all five species have expanded their ranges via migration 'jumps' since the early 1990s (contrary to Harka and Bíró, 2007; who proposed continuous expansion alone). Three main discontinuous population centres can be identified from first occurrence data, all based on ports with important transport hubs (i.e. roll-on/roll-off container transport terminals, rail depots, and motorway links), from where individuals have then spread up- and downstream: 1) the ports of Vienna/Bratislava on the middle Danube (It is not always clear which was the 'introduction' port as both are close, though Vienna is the larger and more likely); 2) the port of Duisburg on the middle (German) Rhine, and especially since 2000; and 3) the Rhine Delta/Rotterdam international sea port.

Surprisingly, however, the extended discontinuous Gobiid 'migration wave' since 1990 does not coincide with an increase in shipping (as proposed, for example, by Wiesner (2005) and 
Wiesner et al. (2000)) but rather with a sudden and dramatic decline in container shipping along the Danube (Figure 7a). Clearly, there must be some previously overlooked factor (or factors) that has driven shipping-related discontinuous expansion since the 1990s, and not before.

A good candidate for such a factor may be geopolitical changes along the corridor over the last 50 years or so. From the end of the Second World War, the Soviet Union had full political and commercial control of most of the Danube (Martin, 2002). Sea-going container shipping was minimal, with most journeys being short-haul and inter-port, mainly serving state-subsidised ports in satellite states of the Soviet Union (the 'Iron Curtain' falling between the ports of Bratislava (then Czechoslovakia) and Vienna (Austria). At this time, therefore, there was low potential for ship-mediated introduction of gobies from their 'native' range into the upper Danube and beyond. In comparison, the steeper increase in shipping along the Rhine over the same period reflects the rapid rebuilding and consequent modernisation of industry along the Rhine valley after the Second World War, with new ports and a deeper channel over much of its length allowing movement of container shipping.

Following the collapse of Communist governments in 1989, much of the economy also collapsed, causing the closure of many of the ports and associated industries along the Danube. This is clearly reflected in the shipping statistics; with figures for 91.8 million tonnes in 1987 reduced to just 20 million tonnes by 1994 (Phase 2 in Figure 7a). The collapse of communist governments, however, opened the way to new East-West trade and the opening of 'Eastern' ports and trade routes to world shipping. It is exactly at this time (1990) that we see the first introductions of round goby via long-haul sea-going container transport to Gdansk on the Baltic coast (Sapota, 2004) and the Laurentian Great Lakes, having passed along the 'central invasion corridor' of the rivers Dneiper, Pripyat, Bug, and Vistula (Figure 1; Jaždžewski, 1980; Maclsaac et al., 2001; Neilson and Stepien, 2011).

Soon after, in 1992, the $171 \mathrm{~km}$ long RMDC was opened, creating a $3500 \mathrm{~km}$ trans-European waterway connecting the North Sea and the Black Sea. While the RMDC is usually put forward as the main 'culprit' contributing to continuous expansion of gobies from the Danube into the Rhine (e.g. see Leuven et al., 2011- "After the opening of the Rhine-Main-Danube waterway in 1992, many fish species originating from the Ponto-Caspian area colonised the Rhine basin"), its actual role as regards continuous (i.e. swimming) migration is debatable and not clearly supported by the first occurrence data presented herein. This does not discount discontinuous migration, however; with first records indicating that a number of species appear to have arrived at Rhine ports before arrival at the RMDC, though 'personal communications' (see Copp et al., 2005) suggest round goby (and possibly tubenose goby; Figure 2) may have passed east-west over the canal continuously soon after their discontinuous introduction to the Rhine (Figure 4). Downstream drift would have ensured rapid joining of the two 'populations' making accurate dating difficult. Both bighead and monkey goby, however, certainly appeared in the Rhine before being recorded anywhere near the RMDC (Figures 3 and 5). Indeed, the evidence suggests that bighead goby may even have passed into the upper Danube from the Rhine, rather than the other way round (Figure 3), though this is difficult to prove due to the limited data. An identical Rhine-to-Danube colonisation has been observed for some other invasive Ponto-Caspian species along the southern route, such as the Quagga mussel (Dreissena rostriformis bugensis; bij de Vaate, 2010). However, while water pumped from the Danube basin to maintain water levels in the RMDCs 15 locks may have contributed to the passage of Ponto-Caspian macroinvertebrates between the Danube and Rhine, water down-flow on either side of the canal may be limiting continuous upward migration by fish. While it is possible that pumping may have transported juvenile gobies over the RMDC, this is unlikely to have been an important source of colonising fish as a) van Riel et al. (2011) noted very few fish larvae at all ( $\leqslant 2 \%$ of all drifting organisms; species not identified) passing over the canal (and this only from April-August), and b) few goby species had even been registered close to the RMDC before they colonised the Rhine.

The main 'migration wave' of gobies along the Danube (and later Rhine) corridor began during the period 1991 to 2001 (Phase 3 in Figure 7a), a period covering not only the opening of the 
RMDC but also the Balkan/Yugoslavian conflict. In addition to actual fighting, there were two major obstacles to navigation on the Danube during the Yugoslavian civil war; a Serbian imposed transit charge (from 1991) and United Nations sanctions (primarily on oil shipments) enforced by the Western European Union from 1993 to 96 (Martin, 2002). This resulted in a huge increase in smuggling and piracy on the lower/middle Danube, involving both container shipping and smaller vessels. It is unlikely that shippers involved in such activities were overly conscientious as regards ballast treatment. Between 1996 and 1999, traffic started to return to the Danube following the lifting of United Nations sanctions.

In 1999, however, NATO ordered the bombing of Yugoslavian bridges over the Danube, completely blocking navigation at the port of Novi Sad. Rather than prevent Yugoslavian shipping, as intended, this blocked the direct North Sea-Black Sea navigation route for all shipping companies using the Rhine and Danube until the complete removal of the barrier in 2003. As a result, there was a huge increase in shipping to and from Rhine sea ports (as shippers decided to switch to the longer Baltic or Mediterranean routes), and a smaller increase in shipping from ports above Novi Sad (with Eastern shipping companies transferring goods by road or rail to unaffected upstream ports), with the central ports of Vienna and Bratislava on the middle Danube acting as a central transport and cargo handling 'hub' (especially for shipping arriving from the lower Danube). The RMDC benefitted with substantially more traffic than predicted as it provided the only navigable alternative for shipping into Central European and middle-Danubian ports (Figure 7b).

It is throughout this period (1994-2000; phase 3 in Figure 7a) that we see the introduction of bighead, round, monkey (though this may also be through continuous migration) and racer goby to Vienna/Bratislava (Figures 3, 4, 5 and 6) from the lower Danube. This has since been confirmed through mtDNA studies by Ondračková et al. (2012).

All species became established at Rhine sea ports (e.g. Rotterdam and Duisburg) from 2001 onward (phase 4 in Figure 7a). Invasion of gobies at sea ports in this period is likely to have been facilitated by aggressive port expansion at Duisburg from around 1999 onward (e.g. a new rail link and terminal [2001-2005] and a huge new tri-modal container terminal [2002-2008]), which attracted many new cargo handlers and shippers to the port (duisport, 2013). Following introduction at Rhine sea-ports, gobies appear to have spread both upand downstream relatively rapidly. Downstream colonisation through drift of $0+$ juveniles has been highlighted as an important factor in the rapid spread of both round and tubenose gobies following their introduction to the River Dyje in the Czech Republic (Janač et al., 2012, 2013). In the same publications, successful upstream migration (including over two weirs) was also noted between 2008 and 2011 along the River Morava, a non-navigable tributary of the Danube, helped in part by the availability of rip-rap bank stabilisation along the river's channelised banks. Downstream drift and plentiful rip-rap habitat have no doubt also played a major role in the relatively rapid spread of goby species along the Rhine (see also Borcherding et al., 2013). In addition, upstream movement (e.g. to the port at Basel in the upper Swiss Rhine) has no doubt been significantly increased by much higher levels of shipping on the Rhine (see Figure 7a; bij de Vaate, 2010), including pleasure cruisers, which are able to navigate the increased slope/flow and decreased depth of the upper Rhine. Indeed, around $10 \%$ of all Swiss foreign trade passes through the port at Basel (approx. 6 million tonnes), more than the total transported over the RMDC for the same period (J. Borcherding, personal Communication). Janač et al. (2012), Jude and Scott (1996) and Polačik et al. (2008) have all demonstrated that round and tubenose gobies show a significant preference for rip-rap as living, feeding and breeding habitat. Borcherding et al. (2011b), however, found bighead goby at equal densities in mud and rip-rap habitats, possibly helping explain their relatively rapid colonisation of both the Danube and Rhine systems. Indeed, it may be the presence of relatively large 'natural' stretches (or at least significant gaps in channelisation and rip-rap) along the middle- and lower-Danube that has limited continuous movement of some species in the lower/middle Danube. Leuven et al. (2011) also highlighted presence of open niches and increased water temperatures as possibly contributing to their success once introduced into the Rhine. 
In comparison, both monkey and racer goby appear to be less 'invasive' than round, bighead and tubenose goby, having spread less intensively. In monkey goby, a preference for shallow, sandy/muddy habitats Miller, 2003; Borcherding et al., 2013) and backwaters (Haertl et al., 2012) may explain this, i.e. not only will they be less competitive in those ecological niches preferred by round, bighead and tubenose gobies, it is also less likely that they will be detected during surveys based along main rivers or channelised habitats. Along the Austrian stretch of the middle/upper Danube, for example, beaches are of gravel rather than sand or mud (as found in Croatia, Slovakia, Hungary or, indeed, the Rhine). The lack of 'preferred' habitat in the middle- and upper Danube, together with increased slope and a concurrent change in bottom structure, therefore, may have prevented further continuous migration upriver, or even long-term survival once introduced. Monkey goby have recently been introduced into the Rhine at the inland sea-port of Duisburg (Figure 5), however, which has an important role in handling raw materials in addition to its huge container port, including sand and gravel. It is possible, though not proven, that monkey gobies were transported there via transport of wet sand/gravel in open Remorker barges, while further downstream migration may have been aided by presence of preferred habitat, e.g. mudflats and sandbanks, in the Rhine delta system and downstream drift of juveniles (Borcherding et al., 2013).

Outside of their area of continuous expansion, racer goby had only been reported from the industrial harbour at Vienna and the Cikola branch system, part of the Hungarian/Slovak floodplain near Gabčikovo, by the mid-2000s, though by 2011 they had migrated upstream as far as Regensburg in Germany. Such apparent slow spreading is unusual, considering the rapid colonisation of many Polish rivers by both monkey and racer goby reported by Grabowska et al. (2008). A number of reasons were put forward by Grabowska et al. $(2005,2008)$ for the success of racer goby in Polish waters, including foraging plasticity, long spawning period and nest guarding; and yet Jurajda et al. (2005) found that racer gobies were much rarer along the southern corridor, particularly when found in association with round and/or bighead gobies. This suggests that a) different factors may be involved in colonisation and establishment along the southern and central invasion corridors, or that b) the racer goby (and monkey goby) have been inadequately researched along the southern corridor. The authors suggest that further focussed surveys are required at habitats outside of harbours and industrial areas (which may favour round, bighead and tubenose gobies) throughout the southern corridor (especially in backwaters and soft-bottomed habitats), and that more studies are required on competitive exclusion in areas where multiple goby species occur.

Since their introduction, rapid expansion of tubenose, bighead and round goby both up and down the Rhine, and latterly into other river systems connecting to the Danube Delta, raises the serious possibility that large areas of Europe far from the Rhine could be colonised by these species in the very near future. Two new potential invasion corridors can be identified. The first crosses Germany, a system of canals connecting the rivers Ems, Weser, Elbe and Oder with the Vistula in Poland (marked (a) in Figure 1; see also Grabowska et al. 2008). In the second, source populations on the upper Rhine and the Moselle are likely to connect with rivers throughout France, including the Seinne, Loire, Marne and Rhône (and ultimately on to the Mediterranean), via an intricate network of canals (marked (b) in Figure 1). It is along these two new potential corridors that intensive monitoring and protection measures need to be concentrated in order to prevent further widespread invasion by these species throughout mainland Europe and the potential knock-on effects to local fish populations that may follow.

In conclusion, data on first records of occurrence, despite potential bias, clearly confirm shipping (especially to ports acting as important transport hubs) as an important factor in the rapid national and international expansion of Gobiid species from the Black Sea. Unexpectedly, however, geopolitical factors (summarised in Table I) since the Second World War, and especially the Balkan conflict of the 1990s and early 2000s, appear to have been key in regulating where, when and by which routes gobies (and other invasive species) first appear. 
Table I

A suggested timeline of major geopolitical and economic events connected with colonisation of PontoCaspian Gobiids along the Danube/Rhine southern invasion route ('shipping phase' refers to Danube shipping shown in Figure 7a; RMDC = Rhine-Main-Danube Canal).

\begin{tabular}{|l|c|c|l|}
\hline Event & Year & $\begin{array}{l}\text { Shipping } \\
\text { phase }\end{array}$ & \\
\hline $\begin{array}{l}\text { Sip Channel } \\
\text { constructed }\end{array}$ & 1910 & <Phase 1 & $\begin{array}{l}\text { Bighead goby passes through the } \\
\text { Iron Gorge in low numbers }\end{array}$ \\
\hline $\begin{array}{l}\text { Iron Gate Dams } \\
\text { construction }\end{array}$ & $\begin{array}{l}1964 \text { (Dam 1 } \\
\text { opened 1972) }\end{array}$ & Phase 1 1 & $\begin{array}{l}\text { From the 1960s on, monkey (1965), } \\
\text { bighead (1970s), round (1997) and racer goby } \\
\text { (by ship 1999) begin 'continuous' migration } \\
\text { up the Danube }\end{array}$ \\
\hline $\begin{array}{l}\text { Collapse } \\
\text { of Communist } \\
\text { governments }\end{array}$ & 1989 & Phase 2 & $\begin{array}{l}\text { Collapse of Danube shipping. } \\
\text { Increase in trade from former Soviet countries } \\
\text { to the West via central invasion corridor. } \\
\text { Round goby introduced to Baltic and then } \\
\text { Laurentian Great Lakes (1990) }\end{array}$ \\
\hline RMDC opened & 1992 & Phase 2 & $\begin{array}{l}\text { Allows movement between Rhine and Danube. } \\
\text { Start of 'discontinuous' migration via shipping; } \\
\text { 'natural' invasion possible but unconfirmed }\end{array}$ \\
\hline $\begin{array}{l}\text { Yugoslavian/ } \\
\text { Balkan } \\
\text { conflict }\end{array}$ & $1992-2001$ & Phase 3 & $\begin{array}{l}\text { Conflict, transit charges and sanctions } \\
\text { encourage piracy and smuggling. } \\
\text { Bombing of bridges in 1999 blocks } \\
\text { Danube at Novi Sad; } \\
\text { shipping shifts to Rhine ports via northern } \\
\text { invasion corridor or side-steps Novi Sad } \\
\text { by rail/road to upstream ports, } \\
\text { with Vienna as a central transport hub. } \\
\text { Increase in shipping through RMDC. } \\
\text { Introduction of bighead, round, } \\
\text { monkey and racer goby to Vienna/Bratislava } \\
\text { from lower Danube }\end{array}$ \\
\hline $\begin{array}{l}\text { Danube reopened. } \\
\text { Huge investment } \\
\text { into Duisburg port } \\
\text { region (Rhine) }\end{array}$ & $2001-$ & $\begin{array}{l}\text { Danube shipping slow to recover; } \\
\text { Rhine shipping increases. Round, bighead, } \\
\text { racer, tubenose and monkey goby all become } \\
\text { established at main Rhine ports, especially } \\
\text { Rotterdam and Duisburg. All spread rapidly. }\end{array}$ \\
\hline
\end{tabular}

\section{ACKNOWLEDGEMENTS}

This study was supported through grant no. P505/11/1768 of the Grant Agency of the Czech Republic. I would like to thank M. Konečna for reading and commenting on an earlier draft of the manuscript, and two referees for their constructive suggestions.

\section{REFERENCES}

Ahnelt H., 1988. Zum vorkommen der Marmorierten Grundel (Proterorhinus marmoratus (Pallas), Pisces: Gobiidae) in Österreich. [on the occurrence of tubenose goby (Proterorhinus marmoratus (Pallas), Pisces: Gobiidae) in Austria]. Annalen des Naturhistorischen, Museums in Wien, 90, 31-42 (in German).

Ahnelt H., 1989. Die Marmorierte Grundel (Proterorhinus marmoratus (Pallas), Pisces: Gobiidae) ein postglazialer Einwanderer. [The tubenose goby (Proterorhinus marmoratus (Pallas), Pisces: Gobiidae) - a post glacial wanderer]. Österr. Fischerei, 42, 11-14 (in German).

Ahnelt H., Bănărescu P., Spolwind R., Harka Á. and Waidbacher H., 1998. Occurrence and distribution of three Gobiid species (Pisces: Gobiidae) in the middle and upper Danube region - example of different dispersal patterns? Biologia Bratislava, 53, 665-678.

Ahnelt H., Duchkowitsch M., Scattolin G., Zweimüller I., Weissenbacher A., 2001. Neogobius gymnotrachelus (Kessler, 1857) (Teleostei: Gobiidae), die Nackthals-Grundel in Österreich [The racer goby in Austria]. Österreichs Fischerei, 54, 262-266 (in German). 
Balon E.K., 1967. [Evolution of the Danube fish fauna, its recent state and an attempt at a prognosis of further changes following hydro-electric power construction]. Biologické Práce, 13, 3-121 (in Slovak).

Bănărescu P., 1964. Pisces - Osteichthyes. Fauna R. P. Romine, Vol. 13. Academiei Republicii Populare Romine, Bucuresti, 959 (in Romanian).

Bănărescu P., 1970. Die Fische des Ponto-Kaspischen potamophilen Artenkomplexes und die KarpatoKaukasische Disjunction. Hydrobiologia, 11, 135-141 (in German).

Berinkey L., 1972. [Freshwater fishes of Hungary and adjacent regions in the collection of the Museum of Natural History]. Vertebrata Hungarica, 13, 3-24 (in Hungarian).

bij De Vaate A.B., 2010. Some evidence for ballast water transport being the vector of the quagga mussel (Dreissena rostriformis bugensis Andrusov, 1897) introduction into Western Europe and subsequent upstream dispersal in the River Rhine. Aquatic Invasions, 5, 207-209.

bij De Vaate A.B., Jazdzewski K., Ketelaars H.A.M., Gollasch S. and Van der Velda G., 2002. Geographical patterns in range extension of Ponto-Caspian macroinvertebrate species in Europe. Can. J. Fish. Aquat. Sci., 59, 1159-1174.

Bíró P., 1972. Neogobius fluviatilis in Lake Balaton - a Ponto-Caspian goby new to the fauna of Central Europe. J. Fish Biol., 4, 249-255.

Blanc M., Bănărescu P. and Gaudet J.-L., 1971. European inland water fish - A multilingual catalogue. FAO. Fishing News (Books) Ltd, London, 24+393+XIX.

Borcherding J., Gertzen S. and Staas S., 2011a. First record of Pontian Racer Goby, Babka gymnotrachelus (Gobiidae: Teleostei), in the River Rhine, Germany. J. Appl. Ichthyol., 27, 1399-1400.

Borcherding J., Staas S., Krüger S., Ondračková M., Šlapanský L. and Jurajda P., 2011b. Non-native Gobiid species in the lower River Rhine (Germany): recent range extensions and densities. J. Appl. Icthyol., 27, 153-155.

Borcherding J., Dolina M., Heermann L., Knutzen P., Krüger S., Matern S., van Treeck R. and Gertzen S., 2013. Feeding and niche differentiation in three invasive gobies in the Lower Rhine, Germany. Limnologica, 43, 49-58.

Ćaleta M., 2007. Ekološke značajke inthyofaune nizinskog dijela rijeke Save [Ecological characteristics of the ichthyofauna of the Sava River lowlands]. Ph.D. Thesis, Faculty of Science, University of Zagreb, 232 (in Croatian; cit. Piria et al., 2011).

Cammaerts R., Spikmans F., van Kessel N., Verreycken H., Chérot F., Demol T. and Richez S., 2012. Colonization of the Border Meuse area (The Netherlands and Belgium) by the non-native western tubenose goby Proterorhinus semilunaris (Heckel, 1837) (Teleostei, Gobiidae). Aquatic Invasions, 2, 251-258.

Copp G.H., Bianco P.G., Bogutskaya N., Erös T., Falka I., Ferreira M.T., Fox M.G., Freyhof J., Gozlan R.E., Grabowska J., Kováč V., Moreno-Amich R., Naseka A.M., Peňáz M., Povž M., Przybylski M., Robillard M., Russell I.C., Stakènas S., Šumer S., Vila-Gispert A. and Wiesner C., 2005. To be, or not to be, a non-native freshwater fish? J. Appl. Ichthyol., 21, 242-262.

DESTATIS. Statistisches Bundesamt. Wiesbaden, 2012. (last accessed 31.01.2013) https://www. destatis.de/EN/FactsFigures/EconomicSectors/TransportTraffic/GoodsTransport/Tables_/ InlandWaterwaysTransport.html.

Drensky P., 1951. Fishes of Bulgaria. Izd. Bulg. Akad. Nauk. Sofia, 270.

duisport - Web page of the Duisport group. Waves of History - Duisburger Hafen AG (last accessed 18.02.2013) http://www.duisport.de/?page_id=33\&lang=en.

Erös T., 2005. Life history diversifications in the Middle Danubian fish fauna - a conservative perspective. Arch. Hydrobiol. Suppl. 158, Large Rivers, 16, 289-304.

Erös T. and Guti G., 1997. Kessler-geb (Neogobius Kessleri Günther 1861) a Duna magyarországi szakaszán [The first record of Neogobius Kessleri Günther 1861 in the Hungarian section of the Danube]. Halászat., 90, 83-84 (in Hungarian).

Erös T., Sevcsik A. and Tóth B., 2005. Abundance and night-time habitat use patterns of PontoCaspian gobiid species (Pisces, Gobiidae) in the littoral zone of the River Danube, Hungary. J. Appl. Ichthyol., 21, 350-357.

Georgiev Ž.M., 1966. Nekoi novy I malko poznaty popcheti (Gobiidae, Pisces) na Bugarskata ichthyofauna [Some new and little known gobies (Gobiidae, Pisces) of Bulgarian Ichthyofauna]. IzV. NIlryb. Stop., 7, 159-228 (in Bulgarian). 
Grabowska J., 2005. Reproductive biology of racer goby Neogobius gymnotrachelus in the Włocławski Reservoir (Vistula River, Poland). J. Appl. Ichthol., 21, 296-299.

Grabowska J., Pietraszewski D. and Ondračková M., 2008. Tubenose goby Proterorhinus marmoratus (Pallas, 1814) has joined three other Ponto-Caspian gobies in the Vistula River (Poland). Aquatic invasions, 3(2), 261-265.

Guelmino J., 1994. [Gobies in the lower section of the River Tisza]. Halászat., 87, 133 (in Hungarian).

Guti G., Erös T., Szalóky Z. and Tóth B., 2003. [The first record of Neogobius melanostomus Pallas, 1811 in the Hungarian section of the Danube.] Halászat., 96, 116-119 (in Hungarian with English summary).

Guttmann S., 2001. Fischökologische Verhältnisse im Einflußbereich des Kraftwerks Freudenau unter besonderer Berücksichtigung ausgewählter Donauabschnitte im zeitlichen Verlauf [Fish Ecological conditions within the control of the Freudenau power plant, with special consideration for selected sections of the Danube over time]. Diploma Thesis, Department of Hydrobiology, University for Natural Resources, Vienna, 203 (in German).

Györe K., Józsa V., Specziár A. and Turcsányi B., 2001. [Fish census in the Rivers Szamos and Tisza in the context of cyanide pollution from Rumania]. Halászatfejlesztés, 26, 110-152 (in Hungarian).

Haertl M., Cerwenka A.F., Brandner J., Borcherding J., Geist J. and Schliewen U.K., 2012. First record of Babka gymnotrachelus (Kessler, 1857) from Germany (Teleosttei, Gobiidae, Benthophilinae). Spixiana, 35, 155-159.

Harka Á., 1988. [Expansion and East-Hungarian appearance of tubenose goby (Proterorhinus marmoratus)]. Halászat., 81, 94-95 (in Hungarian).

Harka Á., 1990. Zusätzliche verbreitungsgebiete der Marmorierten Grundel (Proterorhinus marmoratus Pallas) in Mitteleuropa [Additional dissemination areas of the Tubenose goby (Proterorhinus marmoratus Pallas) in Central Europe]. Österreichs Fischerei, 43, 262-265 (in German).

Harka Á., 1992. [Fish fauna of the River Drava]. Halászat., 85, 9-12 (in Hungarian).

Harka Á., 1993. A folyami geb (Neogobius fluviatilis) terejeszkedése [Range extension of Neogobius fluviatilis]. Halászat., 86, 180-181 (in Hungarian).

Harka Á. and Bíró P., 2007. New patterns in Danubian distribution of Ponto-Caspian gobies - A result of global climate change and/or canalization? Electronic Journal of Ichthyology, 1-14.

Harka Á. and Jakab T., 2001. A folyami géb (Neogobius fluviatilis) egynyaras ivadékának növekedése és tápáléka a Tisza-tóban [Growth and feeding of one-year-old river goby (Neogobius fluviatilis) in the Kiskore reservoir]. Halászat., 94, 161-164 (in Hungarian).

Hegediš A., Nikcevič M., Mickovič B., Jankovič D., and Andjus R.K., 1991. Discovery of the goby Neogobius gymnotrachelus in Yugoslav fresh waters. Archiv. Bioloških Nauka, Beograd, 43, 39-40.

Hensel K., 1995. Proterorhinus marmoratus (Pallas, 1814) In: Barus V. and Oliva O. (eds): Mihulovici (Petromyzones) a ryby (Osteichthyes). Fauna ČR a SR. Academia, Prague, 28, 431-434 (in Czech).

Holčik J., 2002. [Our gobies and how to distinguish them]. Biodiversita Ichtyofauny České Republiky (IV), 73-78 (in Slovak).

Holčik J., 2003. Changes in the fish fauna and fisheries in the Slovak section of the Danube River: a review. Int. J. Lim. 39, 177-195.

Holčik J., Stráňai I. and Andreji J., 2003. The further advance of Neogobius fluviatilis (Pallas, 1814) (Pisces, Gobiidae) upstream of the Danube. Bioligia Bratislava, 58, 967-973.

Janáč M., Valová Z. and Jurajda P., 2012. Range expansion and habitat preferences of non-native 0+ tubenose goby (Proterorhinus semilunaris) in two lowland rivers in the Danube basin. Fundam. Appl. Limnol., 181, p 73-85.

Janáč M., Šlapanský L., Valová Z., and Jurajda P., 2013. Downstream drift of round goby (Neogobius melanostomus) and tubenose goby (Proterorhinus semilunaris) in their non-native Area. Ecol. Freshw. Fish., doi: 10.1111/eff.12037.

Janković D., 1996. Ichthyofauna of the Danube in the Djerdap area after the construction of the Iron Gate I hydroelectric power system. Acta Universitatis Carolinae, Biologica, 40, 123-131.

Janković D., Hegediś A. and Krpo J., 1987. Taxonomische und ökologische Charaktertiken des Gobius (Neogobius) fluviatilis PALLAS (1811) im jugoslawischen Donauteil [Taxonomic and ecological characterisation of Gobius (Neogobius) fluviatilis Pallas (1811) in the Yugoslav part of the Danube]. Arbeitstagung d. IAD, 26, 266-269 (in German). 
Jaždžewski K., 1980. Range extensions of some gammaridean species in European inland waters caused by human activity. Crustaceana Suppl., 6, 84-107.

Jude D.J., Reider R.H. and Smith G.R., 1992. Establishment of Gobiidae in the Great Lakes Basin. Can. J. Fish. Aq. Sci., 49, 416-421.

Jude D.J. and Scott F.D., 1996. Possible impact of gobies and other introduced species on habitat restoration efforts. Can. J. Fish. Aq. Sci., 53 (Suppl. 1), 136-141.

Jurajda P., Černý J., Polačik M., Valová Z.,Janáč M., Blažek R. and Ondračková M., 2005. The recent distribution and abundance of non-native Neogobius fishes in the Slovak section of the River Danube. J. Appl. Ichthyol., 21, 319-323.

Kalchhauser I., Mutzner P., Hirsch P.E. and Burkhardt-Holm P., 2012. Arrival of round goby Neogobius melanostomus (Pallas, 1814) and bighead goby Ponticola kessleri (Günther, 1861) in the High Rhine (Switzerland). Biolnvasions Records (2013), Volume 2 (in press) (Published online: 22 November 2012, last accessed 14 January 2013) http://www.reabic.net/journals/bir/2012/ Accepted/BIR_2013_Kalchhauser_etal_correctedproof.pdf).

Kautman J., 2000. [Three new fish species of Slovakia]. Biodiverzita Ichthyofauny České Republiky, 3 , 29-36 (in Slovak).

Kautman J., 2001. The first occurrence of Neogobius gymnotrachelus in the Slovak Danube. Folia Zool., $50,79-80$.

Koelbel C., 1874. Über die Identität der Gobius semilunaris Heck. Und G. rubromaculatus Kreisch mit G. marmoratus Pallas. [On the identification of Gobius semilunaris Heckel. and G. rubromaculatus crossed with G. marmoratus Pallas]. Verh. Kais.-K. Zool.-Bot. Ges. Vienna, 24, 569-574 (in German).

Kriesch J., 1873. Ein neuer Gobius. [A new goby]. Verh. Zool.-bot. Ges. Vienna., 23, 369-376 (in German).

Leuven R.S.E.W., van der Velde G., Baijens I., Snijders J., van der Zwart C., Rob Lenders H.J. and Bij de Vaate A., 2009. The River Rhine: a global highway for dispersal of aquatic invasive species. Biol. Invasions, 11, 1989-2008.

Leuven R.S.E.W., Hendricks A.J., Huijbregts M.A.J., Lenders H.J.R., Matthews J. and van der Velde G., 2011. Differences in sensitivity of native and exotic fish species to changes in river temperature. Current Zoology, 57, 852-862.

Lusk S. and Halačka K., 1995. The first finding of the tubenose goby, Proterorhinus marmoratus, in the Czech Republic. Folia Zool., 44, 90-92.

Lusk S., Lusková V., Halačka K. and Lojkásek B., 2000. [Changes in the species composition of the ichthyofauna in the territory of the Czech Republic after 1990]. Biodiverzita ichthyofauny České Republiky, (III), 21-28 (in Czech).

Maclsaac H.J., Grigorovich I.A. and Ricciardi A., 2001. Reassessment of species invasion concepts: the Great Lakes basin as a model. Biol. Invasions, 3, 405-416.

Manné S. and Poulet N., 2008. First record of the western tubenose goby Proterorhinus semilunaris (Heckel, 1837) in France. Knowl. Managt. Aquatic Ecosyst., 389(03), 1-5.

Manné S., Poulet N. and Dembski S., 2013. Colonization of the Rhine basin by non-native gobiids: an update of the situation in France. Knowl. Managt. Aquatic Ecosyst. (in press).

Martin E., 2002. International waterway in Crisis: the case of the River Danube. in: IAME (International Association of Maritime Economists) Panama 2000 Conference Proceedings, 13-15 November 2002, Panama. (last accessed 11.02.2013) www.cepal.org/usi/perfil/iame_papers/proceedings/Martin.doc.

Mihić S. and Andrejevic A., 2012. European policy for the promotion of inland waterway transport a case study of the Danube River; sustainable development - policy and urban development tourism - life science - management and environment. In: Ghenai C. (ed.), InTech, Croatia, ISBN: 978-953-51-0100-0.

Mika F. and Breuer G., 1928. Die fische und Fischerei des ungarischen Fertö (Neusiedlersees). [The fish and fisheries of the Hungarian Fertö (Lake Neusiedl)]. Archivum Balatoni-cum (Tihany), 2, 116-131 (in German).

Miller P.J., 2003. Mugilidae, Atherinidae, Atherinopsidae, Blennidae, Odontobutidae, Gobiidae. The freshwater fishes of Europe, Vol. 8/1/ AULA-Verlag GmbH, Wielbelsheim. 
Molnár k. and Baskar F., 1998. Remarks on the occurrence of some fish species in Danube in connection with the mass occurrence of Kessler's goby, Neogobius kessleri. Halászat., 91, 94-96 (in Hungarian).

Mrakovčič M., Schneider D. and Kerovec M., 1994. Freshwater gobies of Croatia. Period. Biol., 96(4), 441-443.

Neilson M.E. and Stepien C.A., 2009. Escape from the Ponto-Caspian: evolution and biogeography of an endemic goby species flock (Benthophilinae: Gobiidae: Teleostei). Mol. Phylogenet. Evol., 52, 84-102.

Neilson M.E. and Stepien C.A., 2011. Historic speciation and recent colonization of Eurasian monkey gobies (Neogobius fluviatilis and N. Pallasi) revealed by DNA sequences, microsatellites and morphology. Divers. Distrib., 17, 688-702.

Ohayon J.L. and Stepien C.A., 2007. Genetic and biogeographic relationships of the racer goby Neogobius gymnotrachelus (Gobiidae: Teleostei) from introduced and native Eurasian localities. J. Fish Biol., 71 (Suppl. C), 360-370.

Ondračková M., Šimková A., Civáňová K., Vyskočilová M. and Jurajda P., 2012. Parasite diversity and microsatellite variability in native and introduced populations of four Neogobius species (Gobiidae). Parasitology, 139, 1493-1505.

Paintner S. and Seifert K., 2006. First record of round goby, Neogobius melanostomus (Gobiidae), in the German Danube. Lauterbornia, 58, 110-126 (In German).

Pintér K., 1989. [Fishes of Hungary]. 1st edition. Akadémiai Kiadó, Budapest, 202 (in Hungarian).

Pintér K., 2002. Die Fische Ungarns. [Fishes of Hungary]. 2nd edition. Akadémiai Kiadó, Budapest, 222 (in German).

Piria M., Šprem N., Jakovlić I., Tomljanović T., Matulić D. and Treer T., 2011. First record of round goby, Neogobius melanostomus (Pallas, 1814) in the Sava River, Croatia. Aquatic Invasions, 6, 153-S157.

Polačik M., Janač M., Trichkova T., Vassilev M., Keckeis H. and Jurajda P., 2008. The distribution and abundance of the Neogobius fishes in their native range (Bulgaria) with notes on the non-native range in the Danube River. Large Rivers, Fundam. Appl. Limnol./Arch. Hydrobiol., Suppl. 166, 18(1-2), 193-208.

Prantl R., 2001. Überprüfung der Funktionsfähigkeit der Fischaufstiegshilfe am Kraftwerk Freudenau Fischökologische Untersuchungen 2000, Schwerpunkt: Besiedelung der Fischaufstiegshilfe [Checking the operation of the fish ladder at Freudenau - Fish ecological studies in 2000, majoring in colonization of the fish ladder]. Diploma Thesis, Department of Hydrobiology, University for Natural Resources, Vienna, 156 (In German).

Prašek V. and Jurajda P., 2001. Expansion of Proterorhinus marmoratus in the Morava River Basin (Czech Republic, Danube R. watershed). Folia Zool., 54, 189-192.

Reinartz R., Hilbrich T. and Born O., 2000. Nachweis der Marmorierten Grundel (Proterorhinus marmoratus PALLAS, 1811) im unterfränkishen Main bei Eltmann (Rheineinzugsgebiet) [Finding of the tubenose goby (Proterorhinus marmoratus PALLAS, 1811) in the Main-River in lower Franconia near Eltmann (Rheine catchment area)]. Österreichs Fischerei, 53, 192-194 (in German).

Ristić M., 1977. [Freshwater fishes and fishing]. Nolit. Beograd, 332 (in Serbian).

Sallai Z., 2003. [Data on fish fauna of the River Danube in the section between Nesz,ely and sutto]. A Puszta 200, 18, 57-76 (in Hungarian; cit. Harka \& Bíró 2007).

Sapota M.R., 2004. The round goby (Neogobius melanostomus) in the Gulf of Gdansk - a species introduction into the Baltic Sea. Hydrobiologica, 514, 219-224.

Scharbert M.R., 2009. Community patterns and recruitment of fish in a large temperate river floodplain the significance of seasonally varying hydrological conditions and habitat availability. Ph.D.-thesis at the Zoological Institute, University of Cologne, Germany, 157.

Schober E., 2001. Fischökologische Verhältnisse im Einflußbereich des Kraftwerks Wein/Freudenau unter besonderer Berücksichtigung neu geschaffener Habitate auf der Donauinsel [Fish Ecological conditions within the control of the Vienna/Freudenau power plant, with special consideration for newly created habitats on Danubian Islands.] Diploma Thesis, Department of Hydrobiology, University for Natural Resources, Vienna, 148 (in German).

Seifert K. and Hartmann F., 2000. Die Kesslergrundel Neogobius kessleri (Günther 1861), eine neue Fischart in der deutschen Donau [The Kesslergrundel Neogobius kessleri (Günther 1861), a new species in the German Danube]. Lauterbornia, 38, 105-108 (in German). 
Simonović P.D. and Nikolic V.P., 1996. Freshwater species of Serbia: an annotated check list with some faunistic and zoogeographical considerations. Bios (Macedonia, Greece), 4, 137-156.

Simonović P.D., Nikolic V.P. and Skóra K.E., 1996. Vertebral number in Ponto-Caspian gobies: phylogenetic relevance. J. Fish. Biol., 49, 1027-1029.

Simonović P., Paunović M. and Popović S., 2001. Morphology, feeding and reproduction of the Round Goby Neogobius melanostomatus (Pallas), in the Danube River Basin, Yugoslavia. J. Great Lakes Res., 27, 281-289.

Simonović P., Valković B. and Paunović M., 1998. Round goby Neogobius melanostomus, a new PontoCaspian element for Yugoslavia. Folia. Zool., 47, 305-312.

Smirnov A.l., 1986. Perch-likes (gobiids), scorpionfishes, flatfishes, clingfishes, anglerfishes, In: Fauna of Ukraine, Vol. 8, No 5, Kiev: Naukova Dumka., 320 (in Russian; cit. Simonović et al. 1998).

Spangler J., 2005. Danubian Gates. In: McColl R.W. (ed.), Encyclopedia of World Geography, Vol. 1, Facts on File Inc., New York, USA, 1151.

Spindler T. and Chovanec A., 1995. Fischfauna in Österreich [Fish fauna of Austria] Umweltbundesamt, Wein. Monographien, 53, 1-120 (In German).

Stemmer B., 2008. Flussgrundel im Rhein-Gewässersystem [The monkey goby in the Rhine river system]. Natur in NRW, 4, 57-60 (in German).

Sterbetz I., 1963. [Data on the distribution of the European mud-minnow (Umbra krameri Walbaum) and tubenose goby (Proterorhinus marmoratus Pall.)]. Vertebrata Hungarica, 5, 15-18 (in Hungarian).

Strán̆ai I., 1997. [Neogobius kessleri in the Danube River]. Pol'vníctvo a rybárstvo, Bratislava, 49, 33 (in Slovak).

Strán̆ai I. and Andreji J., 2001. Býčko riečny (zatial') posledný invázny druh z čel'de býčkovitých [Monkey goby - (so far) the last of the invasive species of the Gobiid family]. Pol'ovníctvo a rybárstvo, Bratislava, 53, 44-45 (in Slovak).

Strán̆ai I. and Andreji J., 2004. The first report of round goby Neogobius melanostomus (Pisces, Gobiidae) in the waters of Slovakia. Folia Zool., 53, 335-338.

Svetovidov A.N., 1964. Ryby Tschernovo mora [Fishes of the Black Sea]. Nauka. Moscow-Leningrad (in Russian).

Terofal F., 1984. Süsswasserfische [Freshwater fish]. Hungarian/German translation - Schmidt Egon: Édesvízi halak. 1997. Magyar Könyvklub, Budapest, 288 (in German).

Tien N., Winter H., Leeuw de J., Wiegerinck J. and Westerink H., 2003. Jaarrapportage Actieve Vismonitoring Zoete Rijkswateren: Samenstelling van de visstand in de grote rivieren gedurende het winterhalfjaar 2002/2003 [Annual Report of Active Fish Monitoring of Sweet Waterways: Composition of fish stocks in rivers during the winter of 2002/2003]. RIVO, Wageningen (in Dutch).

UNECE (United Nations Economic Commission for Europe) Inland Transport Committee. Policy Segment: Sustainable Transport Development - The Case of Inland Water Transport. Palais des Nations, Geneva, 23 February 2010, 9.

van Beek G.C.W., 2006. The round goby Neogobius melanostomatus first recorded in the Netherlands. Aquat. Invasions, 1, 42-43.

van Kessel M., Dorenbosch M. and Spikmans F., 2009. First record of Pontian monkey goby, Neogobius fluviatilis (Pallas, 1814), in the Dutch Rhine. Aquat. Invasions, 4, 421-424.

van Riel M.C., van der Velde G. and bij de Vaate A., 2011. Dispersal of invasive species by drifting. Current Zoology, 57, 818-827.

Verreycken H., Breine J.J., Snoeks J. and Belpaire C., 2011. First record of the round goby, Neogobius melanostomus (Actinopterygh: Perciformes: Gobiidae) in Belgium. Acta Ichthyologica Piscitoria, 41, 137-140.

Visnjic-jeftic Z. and Hegedis M., 2004. New data of the distribution of the gobies (gen. Neogobius, fam. Gobiidae) in Serbian course of the Danube River. Proc. XI Europ. Congress of Ichthyology, Tallinn, 5-9 Sep. 2004, 76.

von Landwüst C., 2006. Expansion of Proterorhinus marmoratus (Teleostei, Gobiidae) into River Moselle (Germany). Folia Zool., 55, 107-111.

Vutskits G.Y., 1911. [A new fish species of our fauna]. Állattani Közlemények, 31-44 (in Hungarian). 
Weninger V., 2001. Überprüfung der Funktionsfähigkeit der Fischaufstiegshilfe am Kraftwerk Freudenau - Fischökologische Untersuchungen 2000, Schwerpunkt: migration [Checking the operation of the fish ladder at Freudenau - Fish ecological studies in 2000, majoring in migration]. Diploma Thesis, Department of Hydrobiology, University for Natural Resources, Vienna, 156 (In German).

Wiesner C., 2005. New records of non-indigenous gobies (Neogobius sp.) in the Austrian Danube. J. Appl. Ichthyol., 21, 324-327.

Wiesner C., Spolwind R., Waidbacher H., Guttmann S. and Doblinger A., 2000. Erstnachweis der Schwarzmundgrundel Neogobius melanostomus (Pallas, 1814) in Österreich [First record of round goby Neogobius melanostomus (Pallas, 1814) in Austria]. Öster. Fisch., 53, 330-331 (In German).

World Ocean Review 1., 2013. Living with the oceans - A report on the state of the world's oceans (last accessed 14.05.2013) http://www.worldoceanreview.com/en/wor-1/transport/global-shipping.

Zauner G., Pinka P. and Moog O., 2001. Pilotstudie Oberes Donautal - Gewässerökologische Evaluierung neugeschaffener Schotterstrukturen im Stauwurzelbereich des Kraftwerks Aschach [Upper Danube Valley Pilot study - Limnological evaluation of newly created structures in the gravel storage root area of the Aschach power plant]. Study commissioned by Wasserstraßendirektion, Vienna, 133 (in German).

Zweimüller I., Moidl S. and Nimmervoll H., 1996. [A new species for the Austrian Danube - Neogobius kessleri]. Acta. Univ. Carol., Biol., 40, 213-218.

Zweimüller I., Guttmann S., Singer G., Schober E.M. and Weissenbacher A., 2000. Eine neue Fischart für Österreich [A new fish species for Austria - Neogobius syrman] (Nordmann, 1840). Osterr. Fisch., 53, 186-189 (In German). 